Prepared in cooperation with Colorado Springs Utilities, the Colorado Water Conservation Board, and the El Paso County Water Authority

Description and User Manual for a Web-Based Interface to a Transit-Loss Accounting Program for Monument and Fountain Creeks, El Paso and Pueblo Counties, Colorado

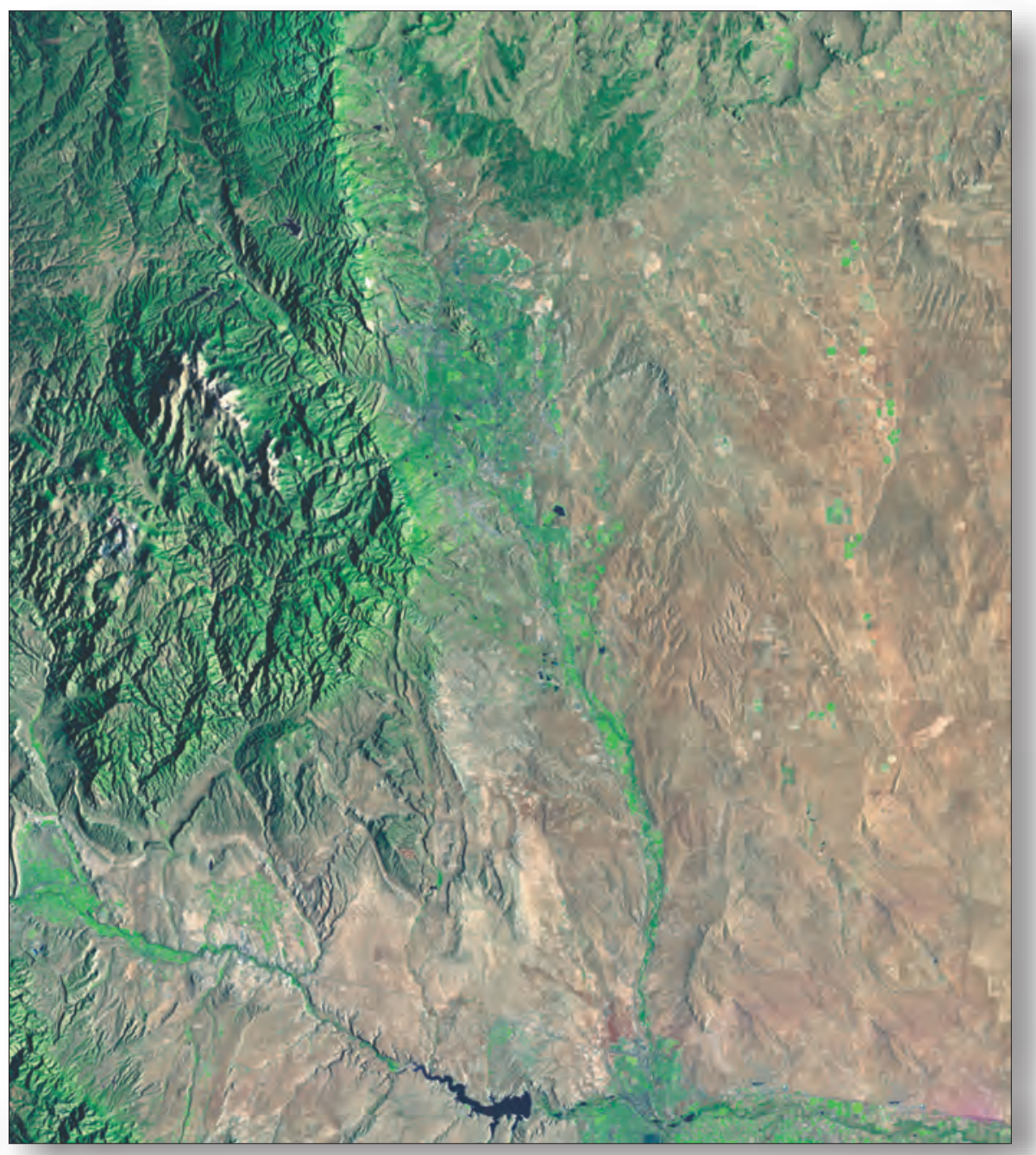

Scientific Investigations Report 2007-5028 


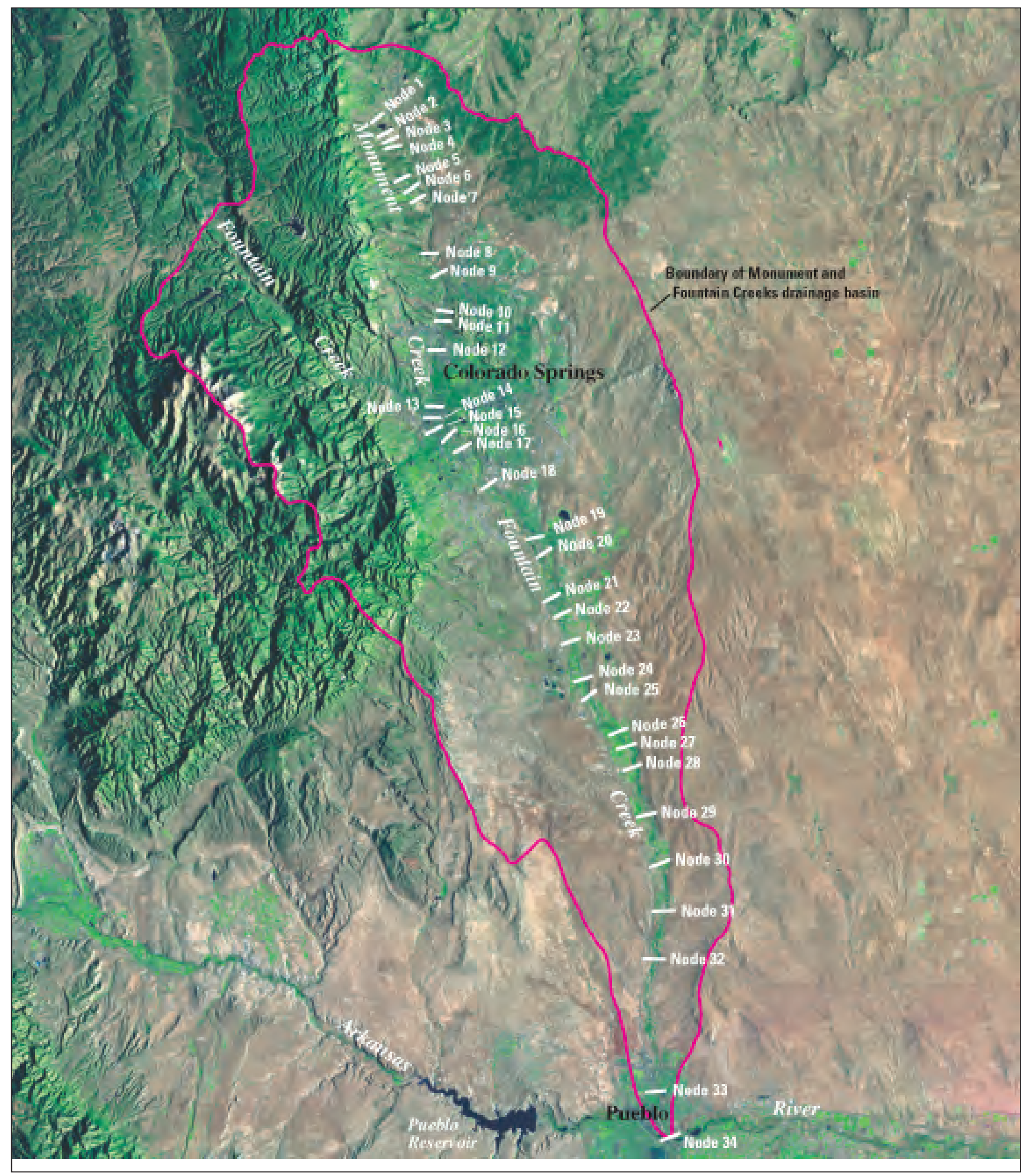

Cover. Landsat2000 image of Monument Creek and Fountain Creek basins and adjacent area. (Data available from U.S. Geological Survey EROS Data Center, Sioux Falls, South Dakota.) 


\section{Description and User Manual for a Web-Based Interface to a Transit-Loss Accounting Program for Monument and Fountain Creeks, El Paso and Pueblo Counties, Colorado}

By Gerhard Kuhn, Gary S. Krammes, and Vivian J. Beal

Prepared in cooperation with

Colorado Springs Utilities, the

Colorado Water Conservation Board, and the

El Paso County Water Authority

Scientific Investigations Report 2007-5028 


\section{U.S. Department of the Interior DIRK KEMPTHORNE, Secretary}

\section{U.S. Geological Survey \\ Mark D. Myers, Director}

\section{U.S. Geological Survey, Reston, Virginia: 2007}

For product and ordering information:

World Wide Web: http://www.usgs.gov/pubprod

Telephone: 1-888-ASK-USGS

For more information on the USGS--the Federal source for science about the Earth, its natural and living resources, natural hazards, and the environment:

World Wide Web: http://www.usgs.gov

Telephone: 1-888-ASK-USGS

Any use of trade, product, or firm names is for descriptive purposes only and does not imply endorsement by the U.S. Government.

Although this report is in the public domain, permission must be secured from the individual copyright owners to reproduce any copyrighted materials contained within this report.

Suggested citation:

Kuhn, Gerhard, Krammes, G.S., and Beal, V.J., 2007, Description and user manual for a Web-based interface to a transitloss accounting program for Monument and Fountain Creeks, El Paso and Pueblo Counties, Colorado: U.S. Geological Survey Scientific Investigations Report 2007-5028, 36 p. 


\section{Contents}

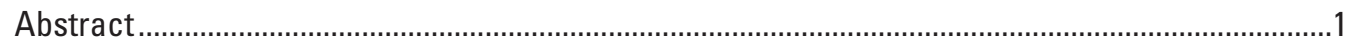

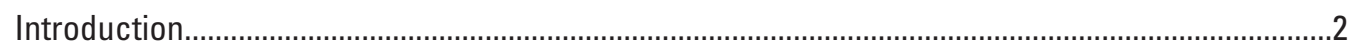

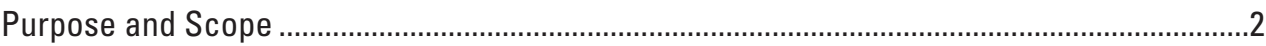

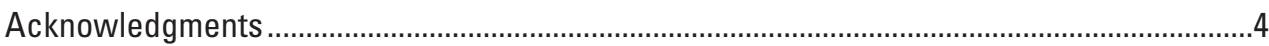

Development of New Transit-Loss Accounting Program.................................................................

Integrated System of Nodes and Subreaches....................................................................

Overview of Operational Methods for Existing Accounting Program.........................................5

Operational Requirements for New Accounting Program..........................................................

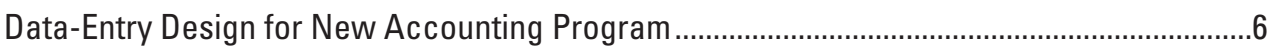

User Manual for Web-Based Interface to Transit-Loss Accounting Program...................................7

Menu-Page Features.....................................................................................................

Data-Entry Form …….....................................................................................................

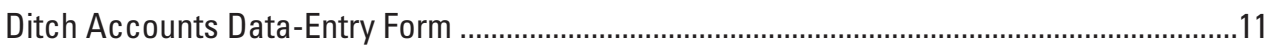

Development of Automated Data-Entry Methods ................................................................11

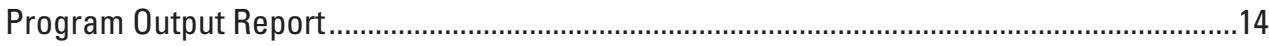

Operational Methods for New Transit-Loss Accounting Program .................................................14

New Method for Reusable Return-Flow Accounting ..........................................................

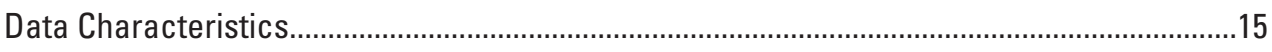

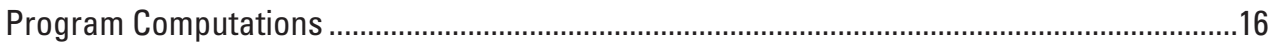

Assumptions Used in the Computations ....................................................................17

Stream-Segment Computations ...............................................................................18

Subreach Computations ...........................................................................................20

Comparison of Results from Existing and New Transit-Loss Accounting Programs..............21

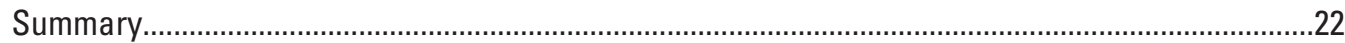

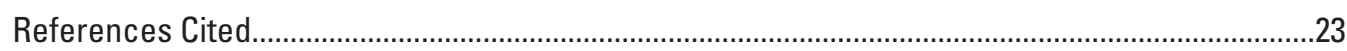

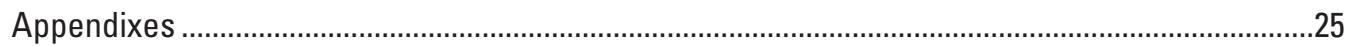

1. Example of data input file for new transit-loss accounting program for Monument and Fountain Creeks............................................................................27

2. Example of output report from new transit-loss accounting program for Monument and Fountain Creeks.......................................................................................30

\section{Plate}

[In pocket]

1. Nodes and Subreaches Along Monument and Fountain Creeks and Location of Streamflow-Gaging Stations, Wastewater-Treatment Facilities, and Diversions Used in New Transit-Loss Accounting Program 


\section{Figures}

1. Map showing study reaches along Monument and Fountain Creeks used in application of transit-loss accounting programs

2-7. Diagrams showing:

2. Menu page of Web-based interface for new transit-loss accounting program for Monument and Fountain Creeks

3. Web-based data-entry form of transit-loss accounting program for Monument and Fountain Creeks. $A$, Section $A ; B$, section $B$; $C$, section $C$; and $D$, section $D$........

4. Ditch accounts data-entry form of new transit-loss accounting program for Monument and Fountain Creeks.

5. Time periods used in computing provisional daily average discharges at streamflow-gaging stations for input to new transit-loss accounting program for Monument and Fountain Creeks.

6. Primary computations for stream-segment loop in new transit-loss accounting program for Monument and Fountain Creeks.

7. Primary computations for subreach loop in new transit-loss accounting program for Monument and Fountain Creeks.

\section{Tables}

1. Comparison of delivery volumes for Colorado Springs Fryingpan-Arkansas transmountain return-flow releases by using existing and new transit-loss accounting programs for Monument and Fountain Creeks during May and June 2006.

2. Streamflow-gaging stations along Monument and Fountain Creeks and at selected tributaries used in new transit-loss accounting program.

3. Input volumes and comparison of delivery volumes for existing and new transit-loss accounting programs for Monument and Fountain Creeks for selected reusable return-flow entities, water year 2006.

\section{Conversion Factors and Datums}

\begin{tabular}{lcl}
\hline \multicolumn{1}{c}{ Multiply } & By & \multicolumn{1}{c}{ To obtain } \\
\hline acre-foot (acre-ft) & 1,233 & cubic meter \\
cubic foot per second $\left(\mathrm{ft}^{3} / \mathrm{s}\right)$ & 0.02832 & cubic meter per second \\
mile $(\mathrm{mi})$ & 1.609 & kilometer \\
square mile $\left(\mathrm{mi}^{2}\right)$ & 2.590 & square kilometer \\
\hline
\end{tabular}

Vertical coordinate information is referenced to the North American Vertical Datum of 1988 (NAVD 88).

Horizontal coordinate information is referenced to the North American Datum of 1983 (NAD 83). 


\section{Abbreviations, Acronyms, and Definition of Terms}

CSU
CDWR
CSV
CWCB
EPCWA
FTP
Imported water

Native water

Nontributary ground water

NSF

Return flow

Reusable water

RRF

Station

Transmountain water

USGS

Water year

WWTF
Colorado Springs Utilities

Colorado Division of Water Resources

Comma-separated values

Colorado Water Conservation Board

El Paso County Water Authority

File transfer protocol

Water that is taken from one basin (watershed) for use in a different basin; hence, the imported water is not a natural part of the water supply in the basin of use (Radosevich and others, 1976, p. 88-89). The cited reference uses the term "foreign water," but "imported water" is used herein

Surface and underground waters naturally occurring in a watershed (Waskom and Neibauer, 2004)

Underground water in an aquifer which is situated so that it neither draws from nor contributes to a natural surface stream in any measurable degree (Waskom and Neibauer, 2004)

Native streamflow (or discharge)

The amount of water that reaches a surface- or ground-water source after it has been released from the point of use and thus becomes available for further reuse (Waskom and Neibauer, 2004)

As used in this report, reusable water is any type of imported (or nontributary) water (including transmountain water) and incorporates the concepts of (1) "reuse" of imported (or nontributary) water, or the subsequent use for the same purpose as the original use; (2) "successive use" of imported (or nontributary) water, or the subsequent use for a different purpose; and (3) the "right of disposition," or the right to sell, lease, exchange, or otherwise dispose of imported (or nontributary) water return flows (Radosevich and others, 1976, p. 93)

Reusable return flow

Streamflow-gaging station

A type of imported water that is imported across the Continental Divide

\section{U.S. Geological Survey}

A continuous 12-month period representing an annual hydrologic cycle selected to present data relative to hydrologic or meteorological phenomena. The water year used by the U.S. Geological Survey (and herein) runs from October 1 through September 30 and is designated by the year in which it ends

Wastewater-treatment facility 


\title{
Description and User Manual for a Web-Based Interface to a Transit-Loss Accounting Program for Monument and Fountain Creeks, El Paso and Pueblo Counties, Colorado
}

\author{
By Gerhard Kuhn, Gary S. Krammes, and Vivian J. Beal'
}

\section{Abstract}

The U.S. Geological Survey, in cooperation with Colorado Springs Utilities, the Colorado Water Conservation Board, and the El Paso County Water Authority, began a study in 2004 with the following objectives: (1) Apply a stream-aquifer model to Monument Creek, (2) use the results of the modeling to develop a transit-loss accounting program for Monument Creek, (3) revise an existing accounting program for Fountain Creek to easily incorporate ongoing and future changes in management of return flows of reusable water, and (4) integrate the two accounting programs into a single program and develop a Web-based interface to the integrated program that incorporates simple and reliable data entry that is automated to the fullest extent possible. This report describes the results of completing objectives (2), (3), and (4) of that study.

The accounting program for Monument Creek was developed first by (1) using the existing accounting program for Fountain Creek as a prototype, (2) incorporating the transit-loss results from a stream-aquifer modeling analysis of Monument Creek, and (3) developing new output reports. The capabilities of the existing accounting program for Fountain Creek then were incorporated into the program for Monument Creek and the output reports were expanded to include Fountain Creek. A Web-based interface to the new transitloss accounting program then was developed that provided automated data entry. An integrated system of 34 nodes and 33 subreaches was integrated by combining the independent node and subreach systems used in the previously completed stream-aquifer modeling studies for the Monument and Fountain Creek reaches.

Important operational criteria that were implemented in the new transit-loss accounting program for Monument and Fountain Creeks included the following: (1) Retain all the reusable water-management capabilities incorporated into the existing accounting program for Fountain Creek; (2) enable daily accounting and transit-loss computations for a variable

${ }^{1}$ Colorado Division of Water Resources. number of reusable return flows discharged into Monument Creek at selected locations; (3) enable diversion of all or a part of a reusable return flow at any selected node for purposes of storage in off-stream reservoirs or other similar types of reusable water management; (4) and provide flexibility in the accounting program to change the number of return-flow entities, the locations at which the return flows discharge into Monument or Fountain Creeks, or the locations to which the return flows are delivered.

The primary component of the Web-based interface is a data-entry form that displays data stored in the accounting program input file; the data-entry form allows for entry and modification of new data, which then is rewritten to the input file. When the data-entry form is displayed, up-to-date discharge data for each station are automatically computed and entered on the data-entry form. Data for native return flows, reusable return flows, reusable return flow diversions, and native diversions also are entered automatically or manually, if needed.

In computing the estimated quantities of reusable return flow and the associated transit losses, the accounting program uses two sets of computations. The first set of computations is made between any two adjacent streamflow-gaging stations (termed "stream-segment loop"); the primary purpose of the stream-segment loop is to estimate the loss or gain in native discharge between the two adjacent streamflow-gaging stations. The second set of computations is made between any two adjacent nodes (termed "subreach loop"); the actual transit-loss computations are made in the subreach loop, using the result from the stream-segment loop. The stream-segment loop is completed for a stream segment, and then the subreach loop is completed for each subreach within the segment. When the subreach loop is completed for all subreaches within a stream segment, the stream-segment loop is initiated for the next stream segment, followed by initiating the subreach loop again; the process continues until transit-loss computations are completed downstream through all subreaches. An iterative process for the two loops is used to ensure that computed downstream reusable return flow and assumed downstream reusable return flow are within a determined criterion. 


\section{Introduction}

In 1988, the U.S. Geological Survey (USGS), in cooperation with Colorado Springs Utilities (CSU), completed a study (Kuhn, 1988) to develop a method to estimate transit losses for return flows of transmountain water (hereinafter, "reusable water") discharged into Fountain Creek at the CSU Las Vegas Street wastewater-treatment facility (WWTF) (fig. 1). Results from applying a stream-aquifer model (Land, 1977) were incorporated into a FORTRAN-based transit-loss accounting program (Kuhn and others, 1998). When the existing accounting program for Fountain Creek was first developed, there was no expectation of a future need to modify the program for changes in management of reusable return flows (hereinafter, "RRFs"). The accounting program was developed for a single purpose as defined in the modeling analysis (Kuhn, 1988). Since implementing the accounting program, however, changes have been made by CSU in management of their RRFs, and other municipal entities along Fountain Creek, such as Fountain, Security, and Widefield, have implemented additional management programs for RRFs. These changes and additions in management of RRFs have necessitated a number of revisions to the accounting program (Kuhn and others, 1998; K.J. Lucey, U.S. Geological Survey, written commun., 2001).

The existing accounting program (Kuhn and others, 1998) has been used continually since April 1989 by the Colorado Division of Water Resources (CDWR) and has provided a tool to effectively administer and manage reusable and native flow rights along Fountain Creek on a daily basis. The CDWR also sees additional needs within the accounting program, such as the capability to determine transit losses for well-augmentation water that may be transported between selected points along Fountain Creek. Moreover, the management of RRFs by CSU and other municipal entities along Fountain Creek likely will change in the near future. In order to easily accommodate current and future changes in management of RRFs, a greater degree of flexibility is needed in the existing accounting program for Fountain Creek.

In addition, during 2006, CSU completed construction of the Northern Water Reclamation Facility adjacent to Monument Creek, a tributary to Fountain Creek, in the northern part of Colorado Springs (fig. 1). This facility will receive some of the wastewater currently discharged into Fountain Creek at the Las Vegas Street WWTF, some of which will consist of RRFs. Management of any RRFs discharged into Monument Creek at the Northern Water Reclamation Facility may include transportation along Monument and Fountain Creeks downstream to some undetermined location; this management requires estimation of transit losses.

A number of other municipal entities in the Monument Creek basin, such as Monument, Palmer Lake, and Woodmoor (fig. 1), also either currently (2007) derive a portion of their water from reusable sources or in the future plan to derive a portion of their water from reusable sources. RRFs for entities along Monument Creek (excluding return flows for CSU discharged at the Northern Water Reclamation Facility) typically will be derived from ground water in the nontributary aquifers of the Denver Basin (Robson, 1987). Return flows in Monument Creek derived from Denver Basin aquifers are fully consumable to extinction, just as transmountain return flows are (Gary Barber, El Paso County Water Authority, written commun., 2006). RRFs from the municipal entities along Monument Creek usually are discharged into Monument Creek or one of its tributaries. Management of any RRFs by these municipal entities likely would include transportation of the RRFs along Monument and Fountain Creek downstream to some undetermined location; this management also requires estimation of transit losses.

Because no methods were available to reliably estimate transit losses along Monument Creek and because of the increasing needs to manage and account for native and reusable water along Monument and Fountain Creeks, the USGS, in cooperation with CSU, the Colorado Water Conservation Board (CWCB), and the El Paso County Water Authority (EPCWA), began a study in 2004 with the following objectives: (1) Apply a stream-aquifer model to Monument Creek, (2) use the results of the modeling to develop a transit-loss accounting program for Monument Creek, (3) revise the existing accounting program for Fountain Creek to easily incorporate ongoing and future changes in management of RRFs, and (4) integrate the two accounting programs into a single program and develop a Web-based interface to the integrated program that incorporates simple and reliable data entry that is automated to the fullest extent possible.

\section{Purpose and Scope}

This report describes (1) development of a new transitloss accounting program for Monument Creek, (2) revision of the existing transit-loss accounting program for Fountain Creek to easily incorporate ongoing and future changes in management of RRFs, and (3) integration of the two transitloss accounting programs and development of a Web-based interface to the integrated program. These descriptions, then, are for completion of objectives (2), (3), and (4) of the cooperative study described in the previous paragraph. Objective (1) (the stream-aquifer modeling) was previously completed and the results are described in Kuhn and Arnold (2006). In addition, this report provides a brief description of how to use the Web-based interface to the new accounting program for data entry and describes the primary input and output files used by the program as well as providing a brief overview of the program transit-loss computations. The descriptions of the new accounting programs are not a line-by-line description of the computer code, but rather a general explanation of the computational steps. Presentation of the computer codes is beyond the scope of this report. 


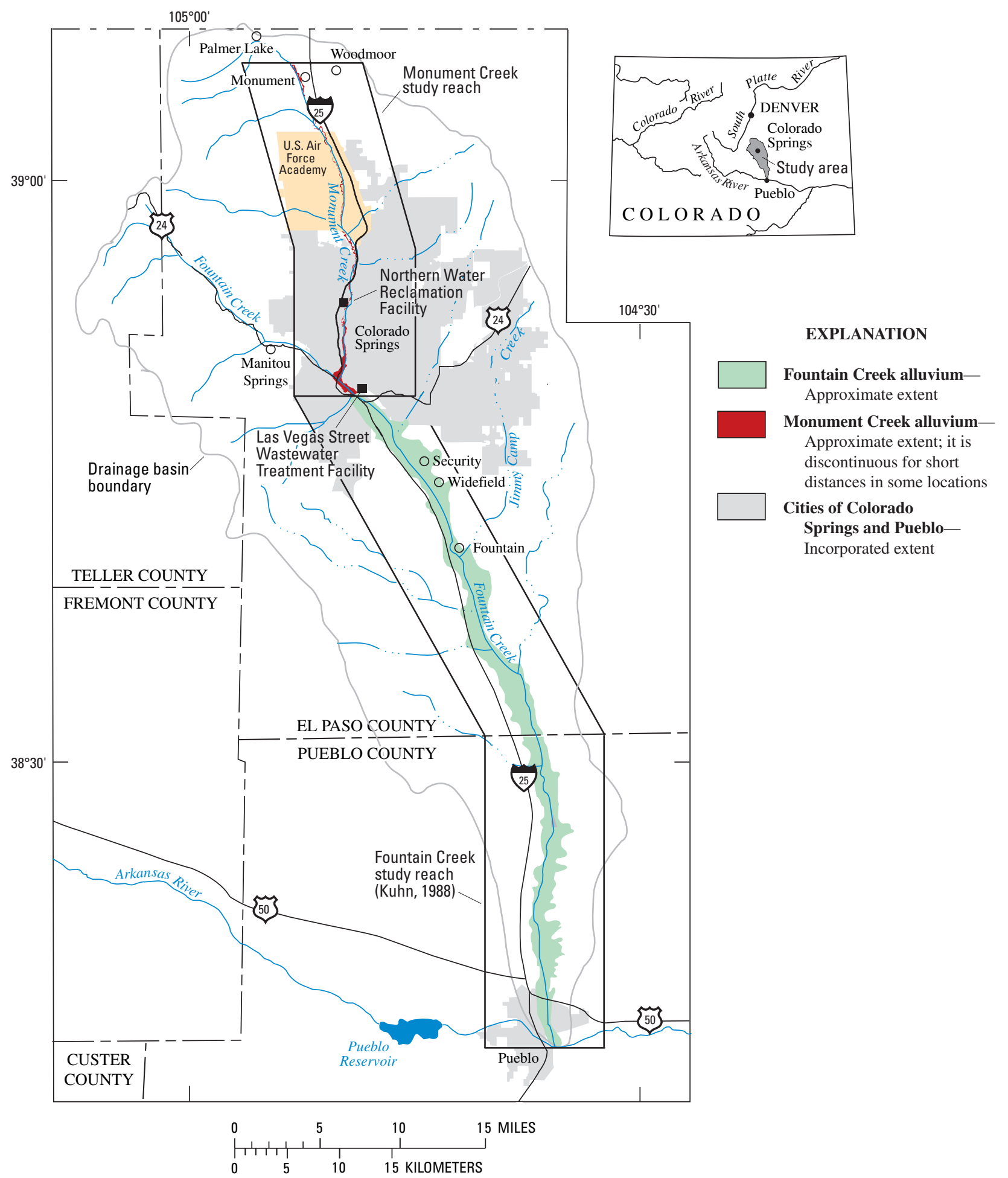

Figure 1. Study reaches along Monument and Fountain Creeks used in application of transit-loss accounting programs. 


\section{Acknowledgments}

The governmental agencies (CSU, CWCB, and EPCWA) participating in the study described herein are referenced in the "Introduction" section; however, input from a number of individuals associated with these agencies has been key to completion of the study as well as to a 2-year planning period prior to the study initiation in 2004. This is true in particular for the EPCWA, which is a consortium of many water-use and water-management agencies throughout El Paso County that are not specifically included in the list of cooperators. The participation of the following individuals, therefore, in the planning and completion of the study described herein is gratefully acknowledged:

\begin{tabular}{cc}
\hline $\begin{array}{c}\text { Water-use or } \\
\text { water-management } \\
\text { agency }\end{array}$ & $\begin{array}{c}\text { Person acknowledged, title, } \\
\text { and additional affiliation }\end{array}$ \\
\hline City of Fountain & $\begin{array}{c}\text { Ron Woolsey, Water Department; } \\
\text { Larry Patterson, Utility Director }\end{array}$ \\
Colorado Center \\
Metropolitan District & Al Testa, District Manager \\
Colorado Department & Bill Tyner, Assistant Division \\
of Water Resources & Engineer; \\
& Rich Snyder, District 10 Water \\
& Commissioner \\
Colorado Springs & Scott Howell, Water-Rights \\
Utilities & Administrator \\
Colorado Water & Steve Miller, Senior Water- \\
Conservation Board & Resource Specialist \\
Donala Water and & Dana Duthie, District Manager; \\
Sanitation District & also Treasurer, EPCWA \\
El Paso County & Cole Emmons, Assistant \\
& County Attorney \\
El Paso County Water & Gary Barber, Manager \\
Authority & \\
Forest Lakes Metropolitan & Ann Nichols, District Manager \\
District & \\
Fountain Mutual Irrigation & Gary Steen, Manager \\
Company & Roy Heald, District Manager \\
Security Water and & \\
Sanitation District & Richard Landreth, Department \\
Town of Monument & of Public Works; \\
Eetty Konarski; Vice President, \\
Triview Metropolitan & Larry Bishop, General Manager; \\
District & also President, EPCWA \\
Widefield Water and & John McGinn, JDS Hydro, \\
Woodmoor Water and & District Consulting Engineers \\
Sanitation District & \\
\hline & \\
\hline &
\end{tabular}

\section{Development of New Transit-Loss Accounting Program}

The first step in developing the new transit-loss accounting program for Monument and Fountain Creeks was to develop an accounting program for Monument Creek by using the results from applying a stream-aquifer model (Land, 1977) to the Monument Creek study reach (Kuhn and Arnold, 2006). A copy of the existing program for Fountain Creek was used as a prototype. To modify this prototype, the first task was to develop a completely new set of subroutines to read (input) the data that would be entered on the Web-based interface (see "Data-Entry Design for New Accounting Program" section). Once the input subroutines were functional, the next step was to incorporate the transit-loss results obtained from applying the streamaquifer model to Monument Creek (Kuhn and Arnold, 2006) into the subroutines that compute the transit losses. The last task for the Monument Creek program was to develop new output reports. [Note: The terms "entry" and "input" are both used in this report in reference to "data." "Data entry" is intended to be associated with entry of data on the Web-based interface to the accounting program. "Data input" is intended to be associated with reading of data by the accounting program.]

The second step was to expand the capability of the new input routines to read additional input data for the Fountain Creek reach (the existing program), modify the transit-loss accounting subroutines to include the additional data for Fountain Creek, and include transit-loss accounting results for Fountain Creek in the new output reports. Thus, the modification of the existing accounting program for Fountain Creek and integration of both programs into a single program were completed more or less simultaneously. The last step of the process was to develop the Web-based interface, which is described in the "User Manual for Web-Based Interface to New Transit-Loss Accounting Program" section.

\section{Integrated System of Nodes and Subreaches}

For application of the stream-aquifer model (Land, 1977) to Monument Creek and Fountain Creek, each study reach (fig. 1) was divided into a system of nodes and subreaches (Kuhn and Arnold, 2006, fig. 2-for Monument Creek; Kuhn, 1988, fig. 6-for Fountain Creek). The system of nodes and subreaches used for application of the stream-aquifer model to the Fountain Creek study reach became an integral part of the existing accounting program for Fountain Creek (Kuhn and others, 1998), and the same would apply to an independent accounting program for Monument Creek, if it were to be developed. In order to develop an integrated accounting program for the two study reaches, the two node-and-subreach systems also needed to be integrated (pl. 1). The nodes and subreaches are numbered consecutively, from the beginning of the Monument Creek study reach downstream to the end of the Fountain Creek study reach; the integrated system has 34 nodes and 33 subreaches (pl. 1). 
Subreaches are subdivisions of the study reach that are assumed to have uniform hydraulic and hydrologic characteristics (Kuhn, 1988, table 3; Kuhn and Arnold, 2006, table 3). Nodes, which delimit the subreaches, were established to be at or near (1) wastewater-treatment facilities (hereinafter, "WWTFs") where reusable water would be discharged into Monument or Fountain Creeks; (2) major tributaries, some of which may have implications in management of reusable water; (3) streamflow diversions; (4) streamflow-gaging stations (hereinafter, "station," or "gaging station"); and (5) other locations where reusable water might be discharged or withdrawn. Within the accounting program, the locations of these features and any associated data, such as quantities of reusable-return flow, native flow or reusable-return flow diversion, and station discharge, are keyed to the nearest node. The flow quantities are routed from one node to the next (through a subreach) and transit losses are estimated for the RRFs. The set of subreaches between any two gaging-station nodes (pl. 1) are referred to as "stream segments" within this report, but are not specifically indicated on plate 1 . In addition, subreaches (pl. 1) do not have specific names but are defined by their upstream and downstream delimiting nodes, which have specific names.

The configuration of nodes and subreaches (pl. 1) upstream from station 07105500 (the Monument Creek study reach) is identical to that used in application of the stream-aquifer model (Kuhn and Arnold, 2006); however, the configuration of nodes and subreaches (pl. 1) downstream from station 07105500 (the Fountain Creek study reach) is different from that used following previous revisions to the existing accounting program for Fountain Creek (Kuhn and others, 1998). Three additional nodes (nodes 21, 24 and 26) were added to the Fountain Creek study reach to provide flexibility to the accounting program for possible future modifications in management of RRFs (see "Operational Requirements for New Accounting Program" section). In addition, the node at station 07106300 (pl. 1) was moved downstream about $0.5 \mathrm{mi}$ from its original location (Kuhn, 1988) because station 07106300 was moved permanently to this location during 1996, after a second major revision to the existing accounting program (Kuhn and others, 1998).

\section{Overview of Operational Methods for Existing Accounting Program}

The user interface to the existing accounting program consists of a sequence of computer-screen queries and manual entry to the requested data. The data entered consisted of any reusable and native return-flow quantities discharged at the Las Vegas Street and other WWTFs, the discharge at each gaging station, and the diversion at each ditch. These data were entered manually to the program for each day of transitloss computations; however, the diversion data, once entered, needed to be reentered only when a diversion quantity changed from the previous day.

With each revision to the existing accounting program (Kuhn and others, 1998; K.J. Lucey, U.S. Geological Survey, written commun., 2001), the computer-screen queries became more numerous and the manual entries more complex. In 2006, manual entry was needed for 13 different return-flow entries, 6 gaging stations, and 24 diversions. A variable name for each return-flow entity was coded into the accounting program as well as a descriptive name for each input variable (return flow, gaging station, and diversion). Because much of the input and output information types (except discharge data) were coded directly into the accounting program, the program would need to be recoded with each change in the management of an existing RRF or addition of a new RRF entity, which sometimes required a substantial expenditure of time. Any future changes in management of RRFs could not be easily accommodated in this type of program structure. [Note: A Web-based interface to the existing accounting program was implemented during July 2006, primarily because of changes in computer equipment; however, the flexibility of the program capabilities did not increase.]

The user interface and computational methods of the existing accounting program are described in more detail in Kuhn and others (1998) in the "Program Computations" section and by figures 4 and 5 (flow charts of the computational procedures) in that report. Any repetition of those descriptions is beyond the scope of this report; however, it is important to note that the actual computation of transit losses in the new accounting program is practically identical to the actual computation of transit losses in the existing accounting program (Kuhn and others, 1998). Some description of the computational methods in the new accounting program is presented in the "Operational Methods for New Transit-Loss Accounting Program" section.

\section{Operational Requirements for New Accounting Program}

A number of operational requirements for the integrated transit-loss accounting program for Monument and Fountain Creeks were requested by various water-resource agencies (see "Acknowledgments" section) that helped develop the accounting program. The primary criteria were:

1. Retain all reusable water-management capabilities (Kuhn and others, 1998; K.J. Lucey, U.S. Geological Survey, written commun., 2001) incorporated into the existing accounting program for Fountain Creek.

2. Enable accounting and transit-loss computations for any number of RRFs discharged into Monument Creek at any node (pl. 1), and provide the capability to account for the return flows and any associated transit losses between any two nodes, even to the mouth of Fountain Creek if necessary.

3. Specifically, enable daily accounting and transit-loss computations for different types of transmountain RRFs and other types of RRFs discharged into Monument Creek at the CSU Northern Water Reclamation Facility (node 12, pl. 1). When (within the accounting program) these return flows reach the CSU Las Vegas Street WWTF (node 16, pl. 1), enable the addition of these return flows to similar types of RRFs discharged into Fountain Creek at the downstream facility. 
4. Enable accounting and transit-loss computations for augmentation flows between any two nodes along Monument or Fountain Creeks for delivery to any selected node (pl. 1).

5. Enable diversion (removal from the transit-loss accounting program and transit-loss computations) of all or a part of an RRF at any selected node for purposes of storage in off-stream reservoirs or other similar types of reusablewater management. This diversion capability would be in addition to the existing capability (Kuhn and others, 1998) to divert CSU transmountain return flows at the various ditches along Fountain Creek (pl. 1) to provide supplemental irrigation water.

6. Provide the flexibility in the accounting program to change (a) the number of RRF entities, (b) the node (location) where a return flow may discharge into Monument or Fountain Creeks, and (c) the node to where a RRF is to be delivered.

7. Provide a Web-based interface to the integrated accounting program that automates data entry to the maximum extent possible.

\section{Data-Entry Design for New Accounting Program}

Development of the new accounting program for Monument and Fountain Creeks that incorporates all the criteria listed in the previous section requires a flexible method of data entry. The data-entry method needs to be able to interface with both the Web-based interface and the FORTRANbased accounting program. Although the interface for data entry will be Web-based (hereinafter, "data-entry form"), the transfer of entered data to the accounting program is made through an ASCII (hereinafter, "input") file that would be read by (input to) the FORTRAN-based accounting program. An example of the input file is shown in Appendix 1 at the back of this report. The primary feature of the input file is the use of extra data lines, some of which may be blank, that serve as placeholders for possible future data entries to the accounting program. Although the input file and data-entry form will be somewhat similar, it is important to understand the structure of the input file and how it provides flexibility to the accounting program; the data-entry form will be described later in the "Data-Entry Form" section.

The first line of the input file contains the date of the previous or current run of the accounting program. Several types of data follow the date and are identified by the first two letters of each data line. The letter codes and types of data are as follows:

ST, main-stream gaging station data;

TR, tributary-stream gaging station data;

NR, native return-flow data;

$\mathrm{RR}$, reusable return-flow data;

$\mathrm{RO}$, reusable diversion data for off-stream storage or other similar forms of reusable-water management;

MD, native-flow diversion data along Monument Creek; and

FD, native-flow diversion data along Fountain Creek.
Note that the letter code for the last data line for each type of data is EN (except for code ST) (Appendix 1), which is needed within the accounting program to signify the end of input for each data type. Five data lines follow the last Fountain Creek diversion data type; these last lines are for user comments to be written to the output report. Several data fields, each with a specific length, follow the two-letter datatype code on each line; the data fields are separated by a semicolon (excluding comment lines) and consist of the following:

1. A two-digit number that indicates the sequence within each data type. Data lines with a "99" sequence number are not displayed on the data-entry form. [Note: The datatype code and the sequence number are not separated by a semicolon.]

2. A two-digit number that indicates the node (pl. 1) at which data are entered into accounting program computations, whether it is for station data, return-flow data, or any type of diversion data. For placeholder or blank data lines, the input node is coded as "-1."

3. A varying-width alphabetic field that contains the name of the station, return flow, or diversion, except that the name of gaging stations is preceded by an eight-digit numeric field for the station number.

4. A varying-width numeric field with the discharge value for each station, return flow, or diversion. Native diversions for Fountain Creek (type FD) data lines have three additional numeric fields that are the discharge values for diversion of three types of CSU transmountain return flows (Kuhn and others, 1998). Station data (types ST and TR), native return-flow data (type NR), and Mountain Creek diversion (type MD) data lines do not have any additional data fields after the discharge values.

5. For reusable return-flow (type RR) data lines, the discharge value is followed by a two-digit number that indicates the node to which the RRF is to be delivered; transit loss is computed for the return flow entity from the upstream input node downstream to the delivery node. For placeholder or blank data lines, the delivery node also is coded as "-1."

6. For reusable diversion to off-stream storage (type RO) data lines, the discharge value also is followed by a two-digit number, but in this case, the number indicates the reusable return-flow entity (type RR) from which the reusable diversion is to be subtracted (the RRF source for the diversion). The number is the sequence number (item 1 in this list) of the reusable return-flow entity. For placeholder or blank data lines, the source entity also is coded as "-1."

In the accounting program, the data fields within each data type (Appendix 1) are read into arrays. The arrays are defined and dimensioned in external "common" files (Flynn and others, 1994), which allow the dimension sizes to be changed easily and implemented by only recompiling the 
source code. The dimensions for each data type are set to a value that should not need to be changed in the near future. These dimensions are 20, for main-stream stations; 10, for tributary stations; 10, for native return flows; 100, for RRFs; 20, for RRF diversions to off-stream storage; 5, for Monument Creek native diversions; and 30, for Fountain Creek native (and transmountain) diversions.

The design of the accounting program input file (Appendix 1) provides considerable flexibility for current (2007) and future RRF management scenarios. All management capabilities implemented in the existing accounting program for Fountain Creek (Kuhn and others, 1998; K.J. Lucey, U.S. Geological Survey, written commun., 2001) are retained in the new accounting program through the input file. New management capabilities, such as accounting of augmentation flows or diversion of RRFs to off-stream storage, also are provided for in the new accounting program and the data-input file. Accounting of the various RRF entities and their associated transit losses, as well as native return-flow entities, within the new accounting program will be based on the information provided in the input file to a much greater degree than in the manual data-entry method used in the existing accounting program, in which only discharge data were entered. Because of this, users need a clear understanding of the different types of data and the values to be entered on the data-entry form. For example, errors in the value for input node of an RRF would result in an incorrect computation of transit loss for that RRF. To help avoid errors in data entry, the Web-based interface to the new accounting program is described in the following sections.

\section{User Manual for Web-Based Interface to Transit-Loss Accounting Program}

Both the existing (Kuhn and others, 1998) and the new transit-loss accounting programs were developed and are maintained by personnel in the USGS Colorado Water Science Center, including the numerous input and output files used by the programs. Daily operation of the program is maintained by the CDWR District 10 Water Commissioners, who, in conjunction with the CDWR Division Engineer, administer water rights along Monument and Fountain Creeks. Access to the Web-based interface to the transit-loss accounting program is made through a password-controlled login page. Each reusable return-flow management entity will be able to login to the data-entry form for purposes of entering data; however, only the CDWR District 10 Water Commissioners will have authority to actually run the accounting program.

\section{Menu-Page Features}

Once a user is logged into the Web-based interface, a menu page is displayed (fig. 2). The menu page has links to a number of program features; additional items could be added to the menu page as future needs arise. The first three items on the menu page are to run the accounting program for the next release (computation) date, the previous release date, or the day prior to the previous release date (fig. 2). Each of these menu items will link to and display the data-entry form, which is described in the "Data-Entry Form" section of this report. The capability to rerun the accounting program for one or two previous days (fig. 2) enables recomputation of transit losses when there has been substantial change in previously entered data values, especially for discharge at one or more of the gaging stations. Channel conditions at many stations, especially those on Fountain Creek and on Monument Creek downstream from Cottonwood Creek (pl. 1), often consist of shifting sand, resulting in frequent changes in the stagedischarge relation (Kuhn and others, 1998).

The next menu item displays data for the ditch accounts related to diversion of CSU transmountain return flows; this form (Account Table) is described in the "Ditch Accounts Data-Entry Form" section. The next menu item links to the output reports for the transit-loss computations, which can be viewed and printed for the previous 90 days. A brief description of the content of an output report is provided in the "Program Output Report" section. The menu items under the "Descriptive Information" heading (fig. 2) provide links to the information shown on plate 1 as well as definitions for selected column headings on the data-entry form; no additional description is needed for these items. The last item on the menu page (fig. 2) provides the capability to compute and view station discharges for any date during the previous 30 days.

\section{Data-Entry Form}

The data-entry form is a continuous form when actually viewed but is divided into four sections (fig. $3 A-D$ ) for purposes of display and discussion herein. The first section of the data-entry form displays data for gaging stations and any native return flows (fig. $3 A$ ); a link to view the system of nodes and subreaches (pl. 1) also is provided. Data fields for node, station number, and station name are not user-changeable because these data likely will not change. If these data do change, the change will require simple modification of the input file (appendix 1) by USGS personnel. When the data-entry form is displayed, up-to-date discharge data for each station are automatically computed from the USGS National Water Information System (http://waterdata.usgs.gov/co/nwis/rt) and entered on the data-entry form; discharges that were entered for the date prior to the current release date also are displayed (fig. 3A). Native return-flow data are input following the station discharge data. In this case, the input node and name fields may be modified by the user; the native return-flow discharges for the current release date, in cubic feet per second, also may be entered or modified (if entry is automated) by the user. 


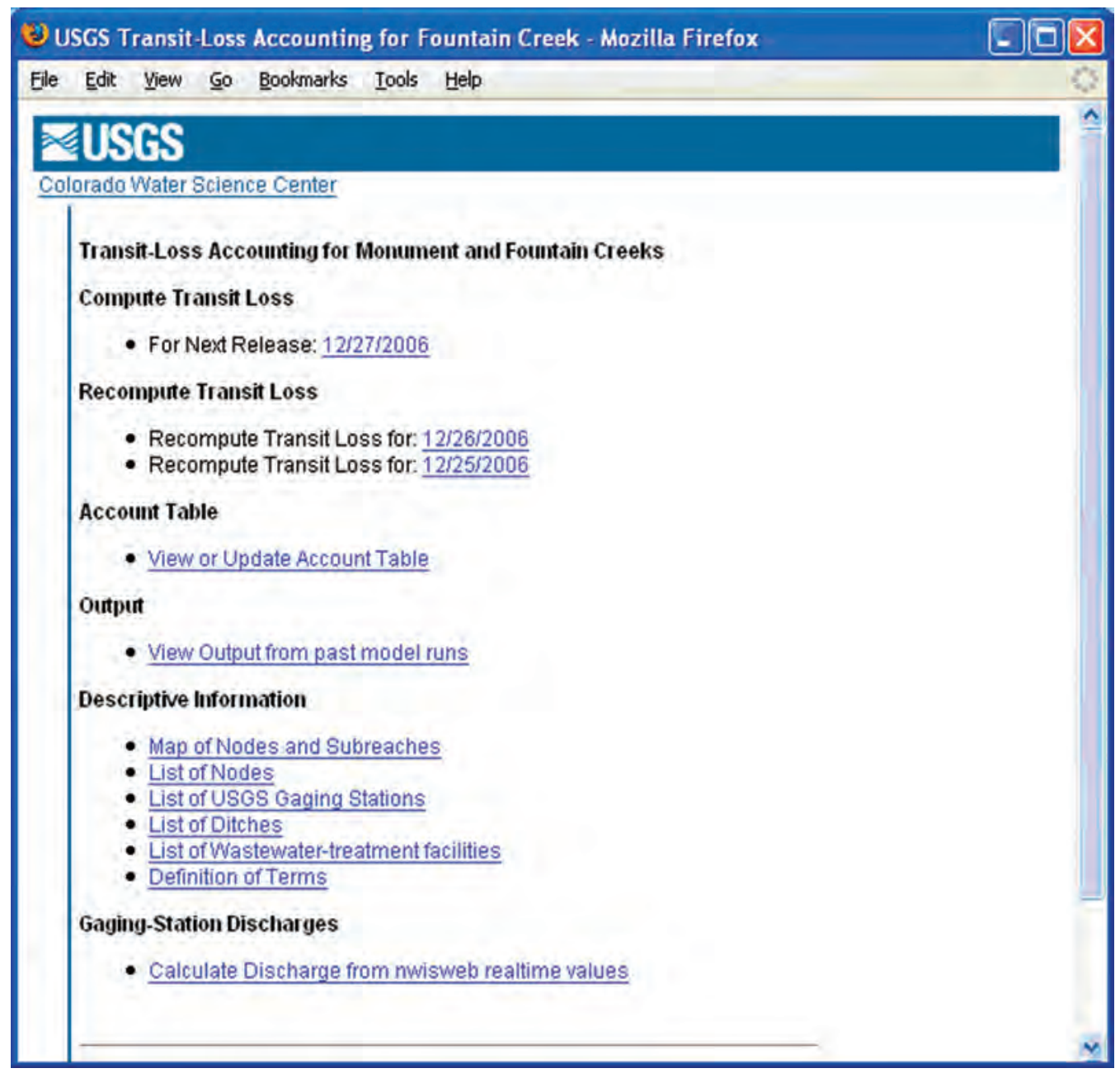

Figure 2. Menu page of Web-based interface for new transit-loss accounting program for Monument and Fountain Creeks.

The next two sections of the data-entry form provide entries for all RRFs (including transmountain return flows) (fig. 3B) and any diversions of RRFs to off-stream storage or other forms of RRF management (fig. $3 C$ ). Input node, delivery node, and return-flow name can be entered or modified by the user; however, once these data have been entered, they are unlikely to be changed. The same applies to the diversion node, return-flow source, and the name for the reusable diversions to off-stream storage data type. Discharge data for the RRFs and reusable diversions also may be entered or modified (if entry is automated) by the user (fig. $3 B, C$ ).

The last section of the data-entry form (fig. $3 D$ ) is for native diversions at the ditches along Monument and Fountain Creeks. The diversion node and ditch name are not user changeable; discharge data for each native diversion as well as discharge for any diversions of CSU transmountain return flows at ditches along Fountain Creek (Kuhn and others, 1988) may be entered or modified (if entry is automated) by the user (fig. 3D). The last part of the data-entry form provides for entry of any comments that the user wants written to the output report. When data entry is complete and all data have been verified, the accounting program can be run (fig. $3 D$ ).
Interaction of the data-entry form (fig. $3 A-D$ ) with the accounting program input file (Appendix 1; also see "DataEntry Design for New Accounting Program" section) follows this sequence:

1. When the "Compute Transit Loss" menu item (fig. 2) is selected, data in the input file (Appendix 1) from the previous program run is displayed in the data-entry form (fig. 3A-D). When either of the "Recompute Transit Loss" menu items (fig. 2) are selected, data in different backup files of the input file are displayed in the dataentry form. In either case, the date in the input file or the backup is read and displayed on the data-entry form as the "Last Transit Loss Computation Date" and that date is incremented by one to display the "Release Date for This Program Run."

2. The most up-to-date daily average discharge data are computed for all necessary gaging stations for the release date and displayed on the data-entry form, as well as the values used for the previous program run. 
$\boldsymbol{A}$

\begin{tabular}{|c|c|c|c|c|c|}
\hline \multicolumn{5}{|c|}{ 러 USGS Iransit-Loss Accounting for Monument and Fountain Creeks - Mozilla Firefox } & \multirow{2}{*}{$\frac{\theta \sqrt{x}}{8}$} \\
\hline \multicolumn{5}{|c|}{ Ele Edt Wow to Eooknaris Iods telp } & \\
\hline \multicolumn{6}{|c|}{ च्वाSB } \\
\hline \multicolumn{6}{|c|}{ Colorado Watar Science Center } \\
\hline \multicolumn{6}{|c|}{ Iransit-Loss Accounting for Monument anul Fountain Creeks } \\
\hline \multicolumn{6}{|c|}{ Displarlmage ormonument creek and Fountain Creek } \\
\hline \multirow{3}{*}{\multicolumn{2}{|c|}{$\begin{array}{l}\text { Todoy is: } \\
\text { Last Transit Loss Computation Date: } \\
\text { Release Date fol this progran nac }\end{array}$}} & \multicolumn{4}{|l|}{ Dev 28, 2006} \\
\hline & & \multicolumn{4}{|l|}{ Dec 24,2006} \\
\hline & & program nus: Dec 25,2006 & \multicolumn{3}{|c|}{ Dec 25,2006} \\
\hline \multicolumn{6}{|c|}{ Daly Mean Dischar yes at USGS Gaging Statious fin cubic feet/sec): } \\
\hline \multicolumn{2}{|c|}{ Nodle Station Number } & Station Name & \multicolumn{2}{|c|}{$\begin{array}{l}\text { Adliusted Discharge for Last Rum Discluarye } \\
\begin{array}{ll}\text { Dec } 25,2006 & \text { Dec } 24,2006\end{array}\end{array}$} & \\
\hline 1 & $07103747 \quad$ & Wonument Creek at Paimer Lake & 4 & 4.00 & \\
\hline 2 & 07103755 & Monument Creek blw Monument Lake & 1 & 1.00 & \\
\hline 7 & 07103780 & Monument Creek abv N. Gate Blvd. & 12 & 12.00 & \\
\hline 11 & 07104000 & Monument creek at Plkeview & 46 & 46.00 & \\
\hline 13 & 07104905 & Monument Creek at Bijou Street & 33 & 25.00 & \\
\hline 15 & 07105500 & Fountain Creek at Colo. Springs & 49 & 49.00 & \\
\hline 17 & 07105530 & Fountain Creek blw Janitell Rod. & 65 & 65.00 & \\
\hline 19 & 07105800 & Fountain Creak at Security & 77 & 77.00 & \\
\hline 23 & 07106000 & Fountain Creeknear Fountain & 133 & 133.00 & \\
\hline 31 & 07106300 & Fountain Creek near Pinon & 72 & 72.00 & \\
\hline 33 & 07106500 & Fountain Creek at Pueblo & 103 & 103.00 & \\
\hline \multicolumn{5}{|c|}{ Tributalies } & \\
\hline 9 & 07103800 & West Monument CreeK at U S AFA & 2 & 200 & \\
\hline 10 & 07103990 & Cottomwood Creek at mouth & 10 & 10.00 & \\
\hline 22 & 07105900 & Jimmy Camp Creek at Fountain & 1 & 1.00 & \\
\hline \multicolumn{6}{|c|}{ Natme Return Flows (in cubic teet / sec): } \\
\hline$\frac{\text { Input }}{\text { Node }}$ & \multicolumn{2}{|r|}{ Name } & \multicolumn{2}{|l|}{ Discharge } & \\
\hline 12 & \multicolumn{2}{|c|}{ Colo. Springs Natve RetrnFlw at N. Rect. Faclity } & 0 & & \\
\hline 16 & \multicolumn{2}{|c|}{ Colo. Springs Natine RetmFlwa at Las Vegas WMTF } & 8.22 & & \\
\hline-1 & & & 0 & & \\
\hline .1 & & & 0 & & \\
\hline-1 & & & 0 & & \\
\hline
\end{tabular}

Figure 3. Web-based data-entry form of transit-loss accounting program for Monument and Fountain Creeks. $A$, Section $A$; $B$, section $B$; $C$, section $C$; and $D$, section $D$.

3. All native return-flow, reusable return-flow, and reusable return-flow diversion data are set to zero for the release date.

4. Native diversion and CSU transmountain diversion data from the date prior to the release date also are displayed on the data-entry form.

5. When entry or modification of all data on the data-entry form has been completed and all data have been verified, "Run program" (fig. 3D) may be selected. At this time, the new data on the data-entry form are rewritten to the input file (Appendix 1).
6. The accounting program then is initiated, reading the input data from the newly written input file. The accounting program only reads from the input file, never writing to the file.

Because entry of all data has not yet been fully automated (see "Development of Automated Data Entry" section), some data will need to be entered manually until data entry is fully automated. When data entry is fully automated, the automatic entry of data probably would replace items (2), (3), and (4) in the above list. 
B 3) USGS Transit-Loss Accounting for Monument and Fountain Creeks - Mozilla Firefox

File Édit Wiew Go Bookmarks Iools Help

Reusahle and Transinountain Return Flows (in cubic feet/sec):

\begin{tabular}{|c|c|c|c|c|}
\hline No. & $\begin{array}{l}\text { Input } \\
\text { Node }\end{array}$ & $\frac{\text { Delivery }}{\text { Node }}$ & Name & Discharge \\
\hline 1 & 12 & 16 & Colo. Springs Transmntn RetrnFlw at N. Recl. Facility & 0 \\
\hline 2 & 12 & 16 & Colo. Springs FRY-ARK RetrnFlw at N. Recl. Facility & 0 \\
\hline 3 & -1 & -1 & Future Colo. Springs RetrnFlw atN. Recl. Facility & 0 \\
\hline 4 & 16 & 16 & Colo. Springs Supplemental Upstream Release & 0 \\
\hline 5 & 16 & 34 & Colo. Springs Transmntn RetrnFlw at Las Vegas WMTF & 40.27 \\
\hline 6 & 16 & 34 & Colo. Springs FRY-ARK RetrnFlw at Las Vegas WhTF & 0 \\
\hline 7 & -1 & -1 & Future Colo. Springs RetrnFlw at Las Vegas WMTF & 0 \\
\hline 8 & 20 & 20 & Fort Carson Transmountain RetrnFlw via Clover Ditch & 0.88 \\
\hline 9 & -1 & -1 & Monument1 Den: Basin RetrnFlw at Tri-Lakes WMTF & 0 \\
\hline 10 & -1 & -1 & Monument2 Den: Basin RetrnFlw at Tri-Lakes WMTF & 0 \\
\hline 11 & -1 & -1 & Monument3 Den: Basin RetrnFlw at Tri-Lakes WMTF & 0 \\
\hline 12 & -1 & -1 & Palmer Lk1 Den. Basin RetrnFlw at Tri-Lakes WMTF & 0 \\
\hline 13 & -1 & -1 & Palmer Lk2 Den. Basin RetrnFlw at Tri-Lakes WMTF & 0 \\
\hline 14 & -1 & -1 & Palmer Lk3 Den. Basin RetrnFlw at Tri-Lakes MMTF & 0 \\
\hline 15 & -1 & -1 & Woodmoor1 Dè, Basin RetrnFlw at Tri-Lakes WWTF & 0 \\
\hline 16 & -1 & -1 & Woodmoor2 Dèn, Basin RetrnFlw at Tri-Lakes WWTF & 0 \\
\hline 17 & -1 & -1 & Woodmoor3 Den, Basin RetrnFlw at Tri-Lakes WWTF & 0 \\
\hline 18 & -1 & -1 & Donala1 Den. Basin RetrnFlw at Upr. Mon. Regional WMTF & 0 \\
\hline 19 & -1 & -1 & Donala2 Den. Basin RetrnFlw at Upr. Mon. Regional WWTF & 0 \\
\hline 20 & -1 & -1 & Donala3 Den. Basin RetrnFlw at Upr. Mon. Regional WWTF & 0 \\
\hline 21 & -1 & -1 & ForestLks1 Den. Bsn RetrnFlw at Upr. Mon. Regional WMTF & 0 \\
\hline 22 & -1 & -1 & ForestLks2 Den. Bsn RetrnFlw at Upr. Mon. Regional WMTF & 0 \\
\hline 23 & -1 & -1 & ForestLks3 Den. Bsn RetrnFlw at Upr. Mon. Regional WWTF & 0 \\
\hline 24 & -1 & -1 & Triview1 Den. Basin RetrnFlw at Upr. Mon. Regional MWTF & 0 \\
\hline 25 & -1 & -1 & Triview2 Den. Basin RetrnF/w at Upr. Mon. Regional WMTF & 0 \\
\hline 26 & -1 & -1 & Triview3 Den. Basin RetrnFlw at Upr. Mon. Regional MWTF & 0 \\
\hline 27 & 16 & 34 & Stratmoor Hills Fry-Ark RetrnFlw at Las Vegas WMTF & 0 \\
\hline 28 & 19 & 34 & Security FRY-ARK RetrnFlw at Security WMTF & 0 \\
\hline 29 & 19 & 34 & Widefield FRY-ARK RetrnFlw at Widefield WWTF & 0 \\
\hline 30 & 19 & 34 & Fountain FRY-ARKRetrnFlw at Widefield WMTF & 0 \\
\hline 31 & 19 & 34 & Fountain Supplemental Flow at Cruse Gulch & 0 \\
\hline 32 & 19 & 34 & Widefield Supplemental Flow at Cruse Gulch & 0 \\
\hline 33 & 19 & 34 & FMIC 2250 Supplemental Flow at Cruse Gulch & 0 \\
\hline 34 & 23 & 34 & Fountain FRY-ARKRetrnFlw at Fountain WWTF & 0 \\
\hline 35 & -1 & -1 & & 0 \\
\hline
\end{tabular}

Figure 3. Web-based data-entry form of transit-loss accounting program for Monument and Fountain Creeks. A, Section $A$; $B$, section $\mathrm{B} ; C$, section $\mathrm{C}$; and $D$, section $\mathrm{D}$-Continued. 


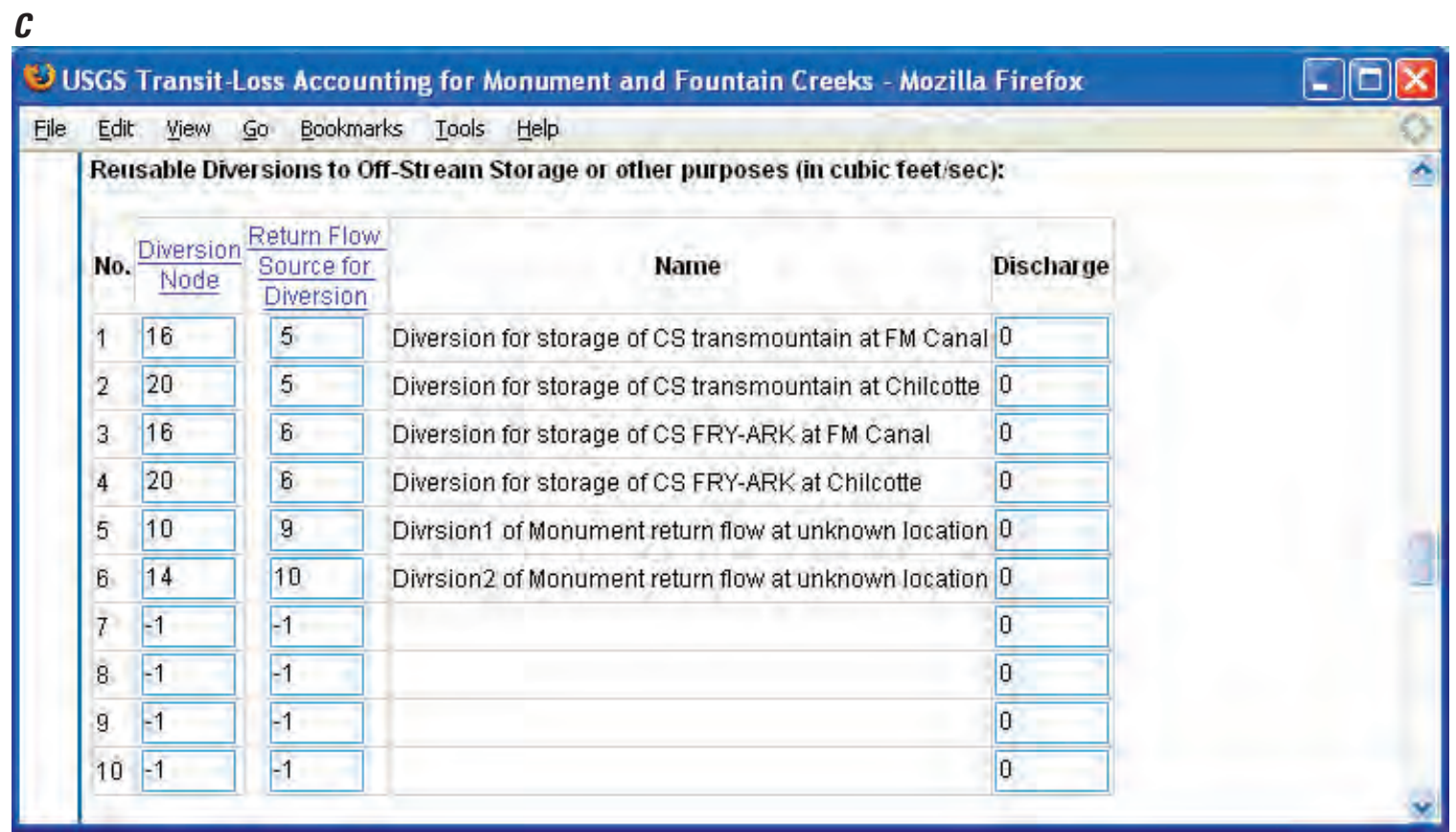

Figure 3. Web-based data-entry form of transit-loss accounting program for Monument and Fountain Creeks. $A$, Section $A$; $B$, section $B ; C$, section $C$; and $D$, section $D$-Continued.

\section{Ditch Accounts Data-Entry Form}

The ditch accounts data-entry form (fig. 4) is used to specify or revise the quantity of water (in acre-feet) available in "purchased" and "used" transmountain diversion accounts. The purchased value indicates the volume of CSU transmountain return flow available for diversion by any of the ditches along Fountain Creek (pl. 1; fig. 3D) during the current year, and the used value indicates how much of the purchased quantity has been used (Kuhn and others, 1998). Transmountain diversions are not made by ditches along Monument Creek because no transmountain return flows are released to the stream upstream from the diversions.

Typically, all ditch accounts data will be set to zero sometime before the beginning of the irrigation season (about April 1) by using the ditch accounts data-entry form. At any time during the irrigation season, any ditch along Fountain Creek may elect to purchase some volume of CSU transmountain return flow (a purchase "on paper"), which will enable that ditch to divert some CSU transmountain return flow whenever it is needed to supplement native diversions. The new purchased volumes also are entered by using the ditch accounts data-entry form. The used volumes are calculated in the accounting program and both the purchased and used values are written daily to a permanent data file, which is read into the ditch accounts data-entry form (fig. 4) whenever this menu item is selected (fig. 2). Whenever the ditch-accounts data are to be changed, the values entered on the ditch accounts data-entry form should be the new total value rather than any incremental or additional value. Whenever a printed copy of the ditch-accounts data is needed, the form (fig. 4) can be printed; the ditch-accounts data are not part of the daily output report, as in the case of the existing accounting program for Fountain Creek (Kuhn and others, 1998).

\section{Development of Automated Data-Entry Methods}

During the initial development of the Web-based interface, it was envisioned that each RRF management entity would login to the Web page for purposes of entering data on the data-entry form. However, the protocols of this method were not easy to define, the method seemed cumbersome, and it failed to automate entry of data, resulting in inefficiency in using the Web-based interface. Therefore, during the last few weeks of the study, development of an alternate method to automate data entry was initiated by the CDWR office in Pueblo (Bill Tyner, Colorado Division of Water Resources, written commun., 2006).

The automated data-entry method would be based on a recently developed method to automate data entry for computerized administration and management of hydrologic data in the Arkansas River Basin in Colorado, termed the "Arkansas River Accounting System." To implement the Arkansas River Accounting System, the CDWR established a file transfer protocol (FTP) site and requested that the various datacollection entities in the Arkansas River basin provide data to the FTP site in comma-separated values (CSV) format. Data sent to the FTP site are automatically retrieved by the CDWR and imported into a variety of Excel spreadsheets and other computer applications for data processing and generation of 
D

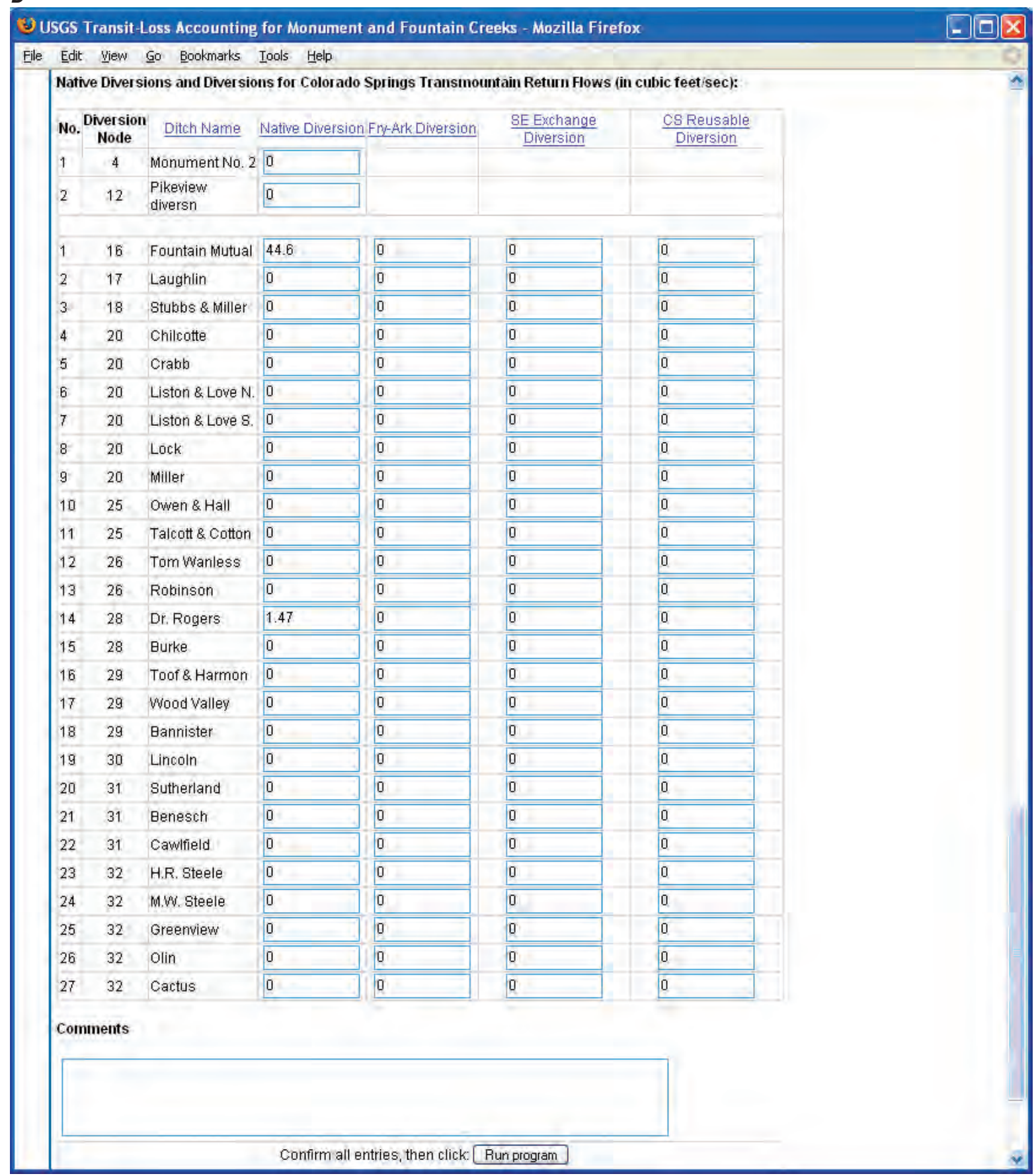

Figure 3. Web-based data-entry form of transit-loss accounting program for Monument and Fountain Creeks. $A$, Section $\mathrm{A} ; B$, section $\mathrm{B} ; C$, section $\mathrm{C}$; and $D$, section $\mathrm{D}$-Continued.

output reports. The reports and other postprocessing data also are sent to the FTP site where the various data-collection entities can easily access the processed data and output reports. A similar method is being developed for compiling, preprocessing, and postprocessing of data needed for entry into the new transit-loss accounting program for Monument and Fountain Creeks. Development of the automated data-entry method for the transit-loss accounting program will consist of the following:
1. Identify all entities that currently are reporting data for Monument and Fountain Creeks to the CDWR.

2. Meet with each entity to determine methods for transmitting electronic data to the CDWR. If data currently are collected and stored in a proprietary database, it may be necessary to provide an Excel spreadsheet to the entity that will enable transmission of CSV data to the CDWR FTP site. 


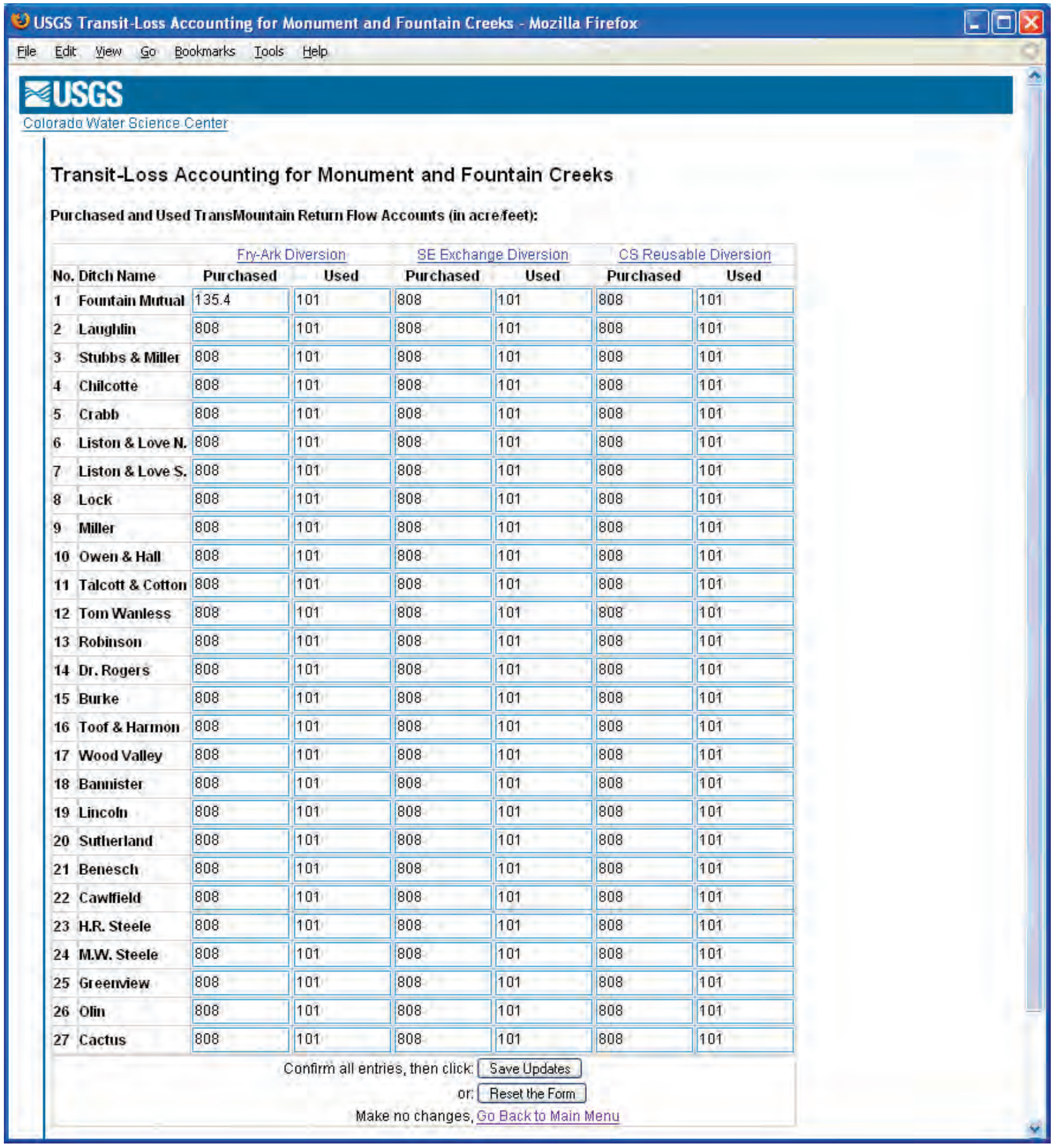

Figure 4. Ditch accounts data-entry form of new transit-loss accounting program for Monument and Fountain Creeks.

3. Develop computer software, including Excel spreadsheets, and design a database that will (a) collect and store all transit-loss data from the FTP site, (b) provide quality assurance and checking of data (such as checking for nonnumeric data or that numeric values are within specified limits), (c) implement a method to report erroneous data back to senders (could be just a phone call), (d) transmit the data to the Web-based interface for automated entry into the data-entry form, and (e) receive and store output from the transit-loss accounting program for integration into Arkansas River Accounting System.
4. Develop a protocol and methods for transmission of data from the FTP site to the Web-based interface to the transit-loss accounting program and entry of the data to the data-entry form (fig. $3 A-D$ ), followed by transmission of program results back to the FTP site.

5. Provide capabilities for CDWR personnel to account for augmentation water from the input location downstream to multiple destinations to insure that adequate replacements for depletions are being made. 
Currently (2007) the method for automated data entry just described is under development, but it is expected to become operational, at least partially, during 2007. Even when data entry is fully automated, the data-entry form will not need to be changed from that shown in figure 3. The data-entry form will provide for a final check of the entered data before the program is run. The various RRF entities will be able to login to the Web-based interface to view program output and other features (fig. 2); however, only the CDWR District 10 Water Commissioners will have authority to enter or modify data and actually run the accounting program.

\section{Program Output Report}

At the conclusion of each daily run of the new accounting program, a multipage output report is written that contains all of the data entered for that date, as well as results of the transit-loss computations; an example output report is shown in Appendix 2 at the back of this report. A brief summary of the content of each page is provided here:

Page 1: Lists data entered for gaging stations and native return flows as well as a list of the nodes to aid in understanding the location of nodes on other pages of the output report.

Page 2: Lists individual data entered for all RRFs, the input node, any diversions made from the return flows, and the amount of return flow at the delivery node.

Page 3: Lists a summary of RRFs, reusable and transmountain diversions, and RRF transit losses for each subreach along Monument and Fountain Creeks.

Page 4: Lists a summary of native flows, tributary inflows, native return flows, native diversions, and gains and losses in native discharge for each subreach along Monument and Fountain Creeks; also lists the total flow in each subreach.

Page 5: Lists the native diversions along Monument and Fountain Creek and the diversions of CSU transmountain return flows at ditches along Fountain Creek and the release amounts for the transmountain diversions, which are computed in the program.

Page 6: Lists the input data for diversions of RRFs for offstream storage or other forms of RRF management in which the return-flow quantity is removed from transit-loss accounting; any output comments specified by the user also are listed on page 6 .

Page 7: Lists the daily, monthly, and annual volumes of reusable return-flow input to the accounting program by each RRF entity. The annual volumes will be used for purposes of allocating costs associated with maintenance of the accounting program and operation of USGS gaging stations that are used for input to the accounting program (G.B. Barber, El Paso County Water Authority, written commun., 2006).

\section{Operational Methods for New Transit- Loss Accounting Program}

The new transit-loss accounting program (as well as the existing program) is a set of FORTRAN subroutines that read a variety of input data, manage multiple arrays of input and program-computed data, read from or write to numerous program files, and generate a multipage output report that summarizes the input data and the transit-loss computations. Detailed descriptions of all these aspects of the program are beyond the scope of the report; however, a description of how actual transit-loss computations are made will be provided here. The program components that perform the actual transit-loss computations use the previously described system of nodes and subreaches (pl. 1) and incorporate the results of applying the stream-aquifer model to the Monument Creek (Kuhn and Arnold, 2006) and Fountain Creek (Kuhn, 1988) reaches. Although numerous revisions have been made to the existing accounting program and a new accounting program (described herein) has been developed, the methodology of the actual transit-loss computations has remained constant.

\section{New Method for Reusable Return-Flow Accounting}

In the new accounting program, an important change has been made in the accounting of RRFs and the associated transit losses. In the existing accounting program, transit losses for each RRF entity were computed independently. To accomplish this, the subroutine that performs the actual transit-loss computation was duplicated and modified as needed for each new RRF entity that was added to the program through time. However, this methodology was not feasible in the new program in order to facilitate the required operational flexibility (see "Operational Requirements for New Accounting Program" section), Therefore, to achieve the required flexibility, discharges for all RRF entities are summed together for the transit-loss computations using a single subroutine rather than using many duplicates of this subroutine.

In order to account for individual RRF entities, a percentage value is computed for each entity, which represents that entity's proportion of the total flow. The percentages first are computed at the upstream node of a subreach after all necessary adjustments of the RRFs; then transit losses are computed for the summed RRFs moving through the current subreach; and lastly, the previously computed percentages are used to compute the RRF quantity for each individual entity at the downstream node of the subreach. The process then repeats for the next subreach. Not only does this new method provide the flexibility needed, but the method also is more similar to the simulation of streamflow in the stream-aquifer modeling (Kuhn and Arnold, 2006; Kuhn, 1988), in which streamflow was divided into two flow components, and it is 
more hydrologically defensible than that used in the existing program (Kuhn and others, 1998), in which computed native discharges needed to be readjusted after the program cycled through the various transit-loss subroutines for the different RRF entities (U.S. Geological Survey, Memorandum to the Record, 1995; on file in Colorado Water Science Center Southeast Colorado Office, Pueblo, Colorado).

Although this new method of accounting for RRFs will have little effect on long-term transit-loss computations (see "Comparison of Results from Existing and New Transit-Loss Accounting Programs" section), there may be a noticeable effect on daily accounting of an RRF whenever the flow value becomes zero after being larger than zero previously, especially along Fountain Creek. This situation is best understood through an example - the transit-loss computations for CSU Fryingpan-Arkansas transmountain return flows during May 31-June 26, 2006 (table 1).

Table 1. Comparison of delivery volumes for Colorado Springs Fryingpan-Arkansas transmountain return-flow releases by using existing and new transit-loss accounting programs for Monument and Fountain Creeks during May and June 2006.

\begin{tabular}{cccc}
\hline & Release volume & \multicolumn{2}{c}{$\begin{array}{c}\text { Delivery volume } \\
\text { (acre-feet) }\end{array}$} \\
\cline { 3 - 4 } Date & (acre-feet) & $\begin{array}{c}\text { Existing } \\
\text { program }\end{array}$ & $\begin{array}{c}\text { New } \\
\text { program }\end{array}$ \\
\hline May 31 & 2.75 & 0.32 & 3.51 \\
June 1 & .0 & .67 & .0 \\
June 2 & 1.47 & .83 & 1.41 \\
June 3 & 1.43 & .85 & 1.21 \\
June 4 & 1.45 & .89 & 1.13 \\
June 5 & .24 & .93 & .18 \\
June 6 & .0 & .79 & .0 \\
June 7 & .0 & .52 & .0 \\
June 8 & .0 & .28 & .0 \\
June 9 & .0 & .08 & .0 \\
June 10 & .0 & .06 & .0 \\
June 11 & .0 & .04 & .0 \\
June 12 & .0 & .04 & .0 \\
June 13 & .0 & .04 & .0 \\
June 14-26 & .0 & .26 & .0 \\
\hline Total & 7.34 & 6.60 & 7.44 \\
\hline
\end{tabular}

A primary component of transit loss is loss to bank storage (flow of water from a stream to an adjacent alluvial aquifer); losses to bank storage can accrue back to the stream (gains from bank storage) over a period of time (Kuhn, 1988; Kuhn and Arnold, 2006). For the Fountain Creek reach, the time (recovery) period can be about 180 days or longer, but it was determined that accounting of gains from bank storage was reasonable only for a 60-day period (Kuhn, 1988). When an RRF value greater than zero is entered after a period of zero flow, the bank-storage loss initially will be large because there is no history of gains from bank storage, illustrated by the daily delivery volumes when using the existing accounting program (table 1). In addition, when the RRF value again goes to zero, the delivery volumes do not go to zero immediately because of continued gains from bank storage (table 1). On the other hand, when using the new accounting program, the delivery volumes initially are not nearly as small (in this case, actually larger than the release volume on day 1) as when using the existing program; however, when the release volume goes to zero, the delivery volume also goes to zero and there are no long-term gains from bank storage for that RRF entity when using the new accounting program (table 1).

With the new accounting program though, initial bankstorage loss for an RRF entity going from zero to some greater release value will be smaller than with the existing accounting program because the new entity will become a part of the total RRFs, which already will have a 60-day history of gains from bank storage. However, whenever an RRF entity goes to zero from a previously larger release value, the delivery volume also goes to zero because gains from bank storage cannot be allocated to an RRF entity that had a release value of zero. Although there is about a 12 percent difference in the delivered volumes in the example (table 1), the example is for a relatively short period and does not represent a typical RRF release situation. The "Comparison of Results from Existing and New Transit-Loss Accounting Programs" section provides a comparison of transit-loss computations with the existing and new accounting programs for a longer period. (The discussion in this section applies equally to Monument Creek, but the effects will be smaller because the recovery periods are much less than 60 days and the losses to bank storage are much smaller than along Fountain Creek (Kuhn and Arnold, 2006).)

\section{Data Characteristics}

In the existing accounting program, a 24-hour traveltime was assumed for streamflows in Fountain Creek from the Las Vegas Street WWTF downstream to the mouth (Kuhn, 1988). Traveltime for streamflow in the Monument Creek study reach (fig. 1) probably averages about 12 hours (Kuhn, 1991). Management of reusable and native flows in Monument and Fountain Creeks, however, is best made on a 24-hour daily basis because RRFs and diversions are administered and managed on a 24-hour basis (Rich Snyder, Colorado Division of Water Resources, written commun., 2006); therefore, a 24-hour traveltime also was assumed for the entire study reach (pl. 1). Although the 24-hour traveltime assumption for the entire study reach may be inaccurate during a shorter period (1-3 days), the effect on transit-loss computations over a longer period is inconsequential.

To improve the accuracy of the transit-loss computations, daily average discharge data on the data-entry form (fig. 3A) for gaging stations along Monument and Fountain Creeks 
(table 2) are computed for a variable 24-hour time period over a 2-day time period (fig. 5). The first day of the period is the "release" day and the second day is the "reuse" day. Transit-loss computations usually are made 2 days after the release day, except after weekends and holidays, when the computation day may be delayed additionally. The 2- to 4-day delay in application of the accounting program does not have any negative effect on administration and management of native and reusable water rights along Monument and Fountain Creeks. (A 2-day time period for computation of daily average discharge data for gaging stations only along Fountain Creek also is used in the existing program (Kuhn and others, 1998), but the times for each station differ from those in figure 5.)

Daily average discharges on the data-entry form (fig. $3 A$ ) are provisional (subject to revision) because (1) the 24-hour periods (fig. 5) used to compute the discharges are different from a midnight (2400 hours) to midnight period (except for first and last main-stream stations, fig. 5) used in computing published discharge data, and (2) the discharges are computed on a near real-time basis and may be adjusted later with more up-to-date stage-discharge shift data. Reusable and native return-flow discharges and reusable diversions on the data-entry form (fig. 3B, $C$ ) are for a normal 24-hour period because accounting of these flow data always is made for a normal 24-hour period; the values input to the program always are for the release day (fig. 5). Diversion data on the data-entry form (fig. 3D) also are for a normal 24-hour period, because the quantity of flow diverted remains fairly constant from day to day and accounting of diversion data also is based on a normal 24-hour period; diversion data entered on the form also are for the release day. All entered data (figs. 2 and 3) and most of the output results (Appendix 2) are expressed in cubic feet per second, unless noted otherwise.

\section{Program Computations}

In computing the estimated quantities of RRFs and the associated transit losses, the accounting program uses two sets of computations. The first set of computations is made between any two adjacent gaging stations (hereinafter, the "streamsegment loop") (fig. 6); the primary purpose of the streamsegment loop is to estimate the loss or gain in native discharge (hereinafter, "NSF") between the two adjacent gaging stations. The second set of computations is made between any two adjacent nodes (the "subreach loop") (fig. 7); the actual transitloss computations are made in the subreach loop, using the result from the stream-segment loop. The stream-segment loop is completed for a stream segment, and then the subreach loop is completed for each subreach within the segment. When the subreach loop is completed for all subreaches within a stream segment, the stream-segment loop is initiated for the next stream segment, followed again by initiating the subreach loop; the process continues until transit-loss computations are completed downstream through all subreaches. The following discussions and figures 6 and 7 primarily are intended to provide an overview of the transit-loss computations; the computational steps are much more complex than illustrated.

Table 2. Streamflow-gaging stations along Monument and Fountain Creeks and at selected tributaries used in new transit-loss accounting program.

$[--$, not determined $]$

\begin{tabular}{|c|c|c|c|}
\hline $\begin{array}{l}\text { Station number } \\
\text { (plate 1) }\end{array}$ & Station name & $\begin{array}{l}\text { Drainage area } \\
\text { (square miles) }\end{array}$ & $\begin{array}{l}\text { River miles } \\
\text { upstream } \\
\text { from mouth }\end{array}$ \\
\hline 07103747 & Monument Creek at Palmer Lake & 25.9 & 78.3 \\
\hline 07103780 & Monument Creek above Northgate Boulevard at U.S. Air Force Academy & 81.7 & 70.5 \\
\hline 07103800 & West Monument Creek at U.S. Air Force Academy & 14.9 & 63.2 \\
\hline 07104905 & Monument Creek at Bijou Street at Colorado Springs & 235 & 52.7 \\
\hline 07105500 & Fountain Creek at Colorado Springs & 392 & 50.7 \\
\hline 07105530 & Fountain Creek below Janitell Road below Colorado Springs & 413 & 48.4 \\
\hline 07105600 & Sand Creek above mouth at Colorado Springs & 52.5 & 46.0 \\
\hline 07105800 & Fountain Creek at Security & 495 & 42.5 \\
\hline 07106500 & Fountain Creek at Pueblo & 926 & 2.4 \\
\hline${ }^{1} \mathrm{FOUMOCO}$ & Fountain Creek at mouth & -- & 0.0 \\
\hline
\end{tabular}

${ }^{1}$ Station operated by Colorado Division of Water Resources; station not used in transit-loss accounting program, but is used by Division Engineer in administration of reusable water rights. 


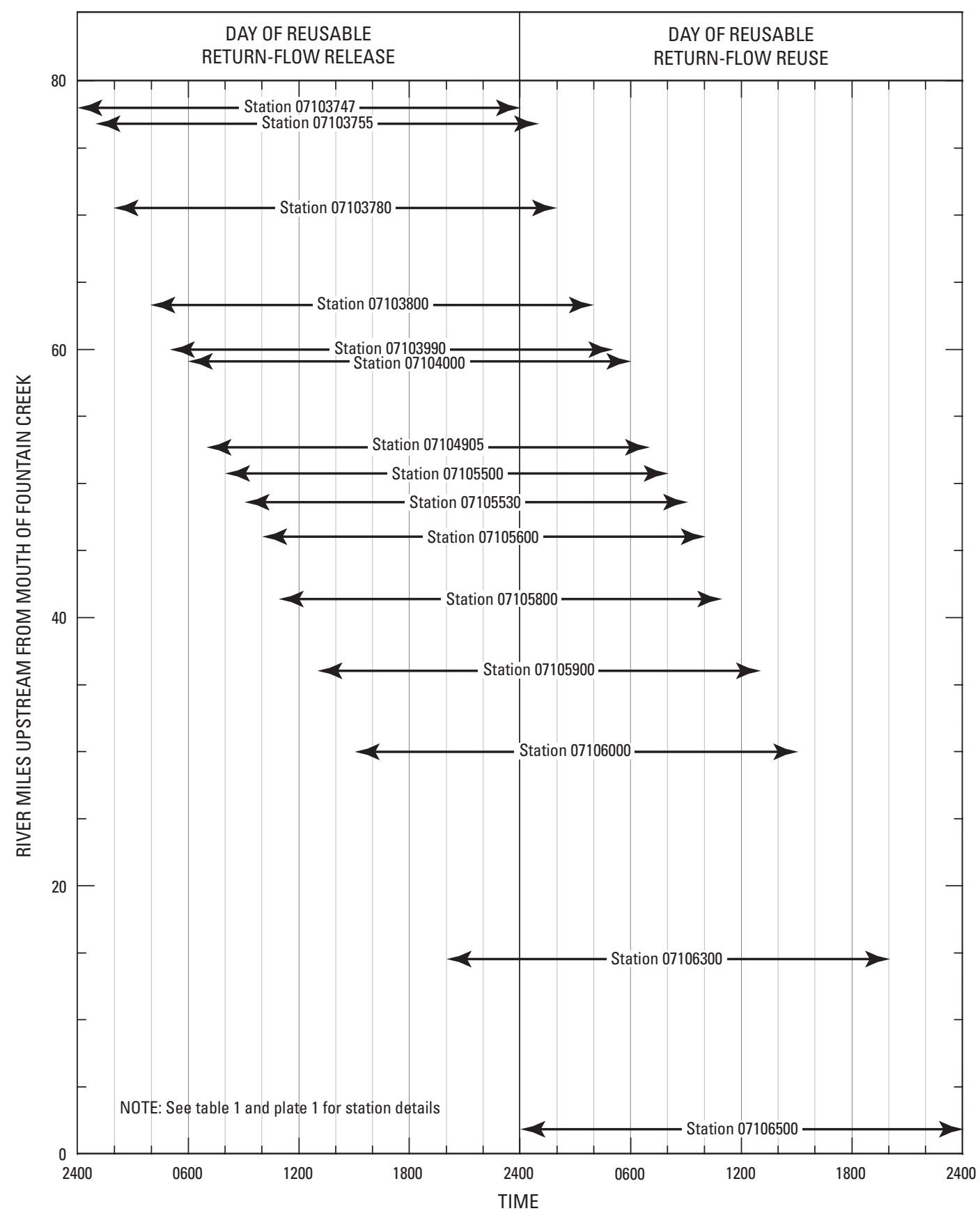

Figure 5. Time periods used in computing provisional daily average discharges at streamflow-gaging stations for input to new transit-loss accounting program for Monument and Fountain Creeks.

\section{Assumptions Used in the Computations}

Two assumptions are incorporated into the computations of estimated transit losses using the accounting program. First, the data on the data-entry form (fig. 3) that are input to the accounting program are assumed to be accurate. Second, for each stream-segment loop it is assumed that the initial quantity of RRF at the downstream gaging station is the same as the quantity at the upstream station. This assumption is necessary because, at this point in the computations, the quantity of RRF at the downstream station is not known.
The computed RRF at the downstream node of the stream segment always will be different from the assumed downstream RRF. An iterative process then begins in which the stream-segment loop is repeated, including all subreach computations within the stream segment. In each repeated iteration, the previously computed downstream RRF is used for the new assumed downstream RRF. When the difference between the assumed and computed downstream RRFs is less than 0.5 percent $\left(0.01 \mathrm{ft}^{3} / \mathrm{s}\right)$, the computations are said to have "converged" and computations move to the next stream segment. 


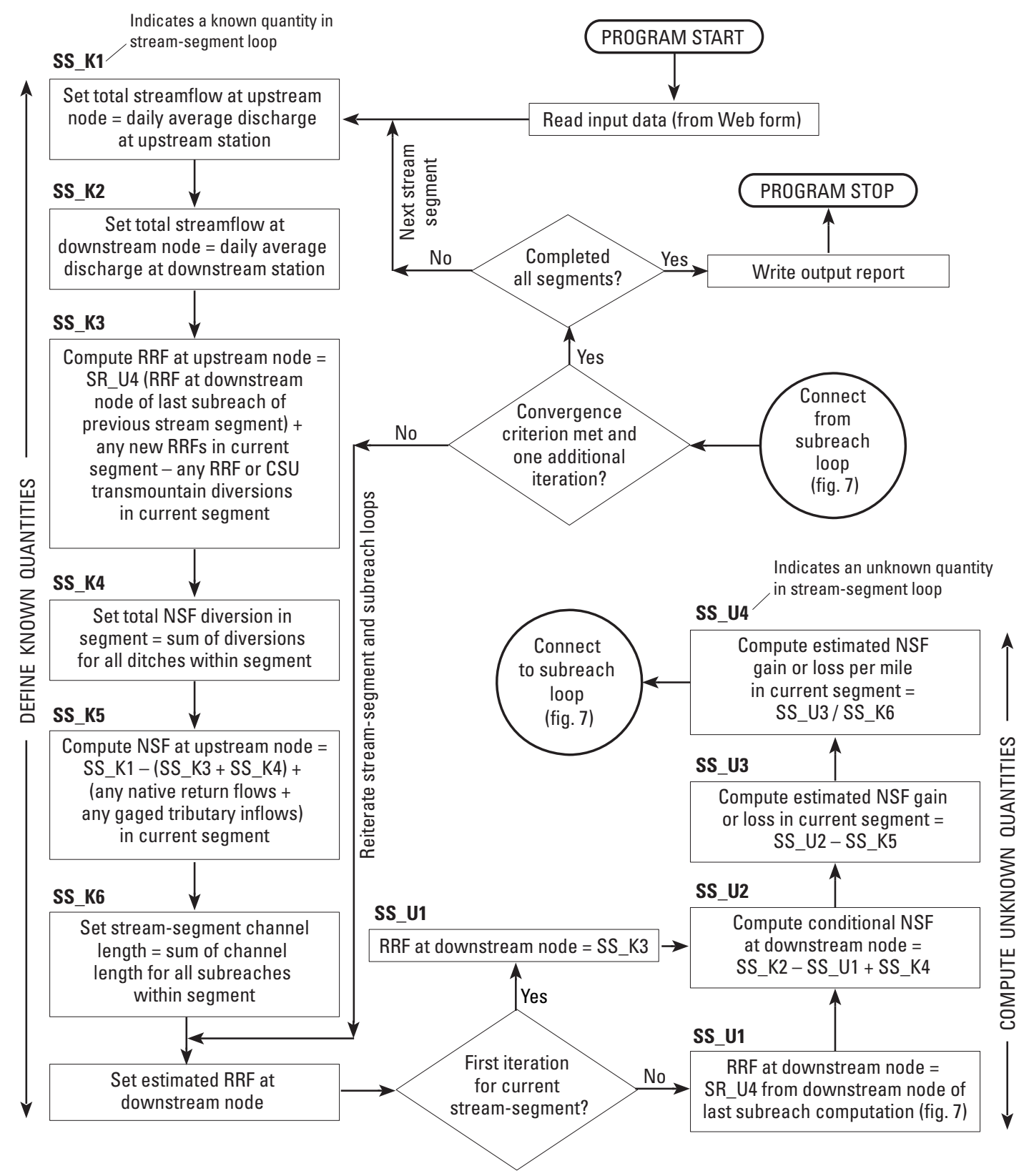

[Note: CSU, Colorado Springs Utilities; NSF, Native streamflow; RRF, Reusable return flow]

Figure 6. Primary computations for stream-segment loop in new transit-loss accounting program for Monument and Fountain Creeks.

\section{Stream-Segment Computations}

The transit-loss computations begin with the streamsegment loop, in which the following known quantities (SS_Kx, where $\mathrm{x}$ is a number) need to be defined (fig. 6):

1. SS_K1, which is the total discharge at the upstream gaging station (node) for the 24-hour time period shown in figure 5 .

2. SS_K2, which is the total discharge at the downstream gaging station (node) for the 24-hour time period shown in figure 5.
3. SS_K3, which is the RRF at the upstream node. For all nodes except node 1 (pl. 1), SS_K2 is equal to SR_U4 (fig. 7), the RRF at the downstream node of the last subreach in the previous stream-segment loop; currently (2007) there are no RRFs at node 1. Discharges for any new RRFs in the current segment are added to, and any discharges for RRF and CSU transmountain diversions in the current segment are subtracted from, the RRFs incoming from the last subreach of the previous segment before the stream-segment computations begin. 


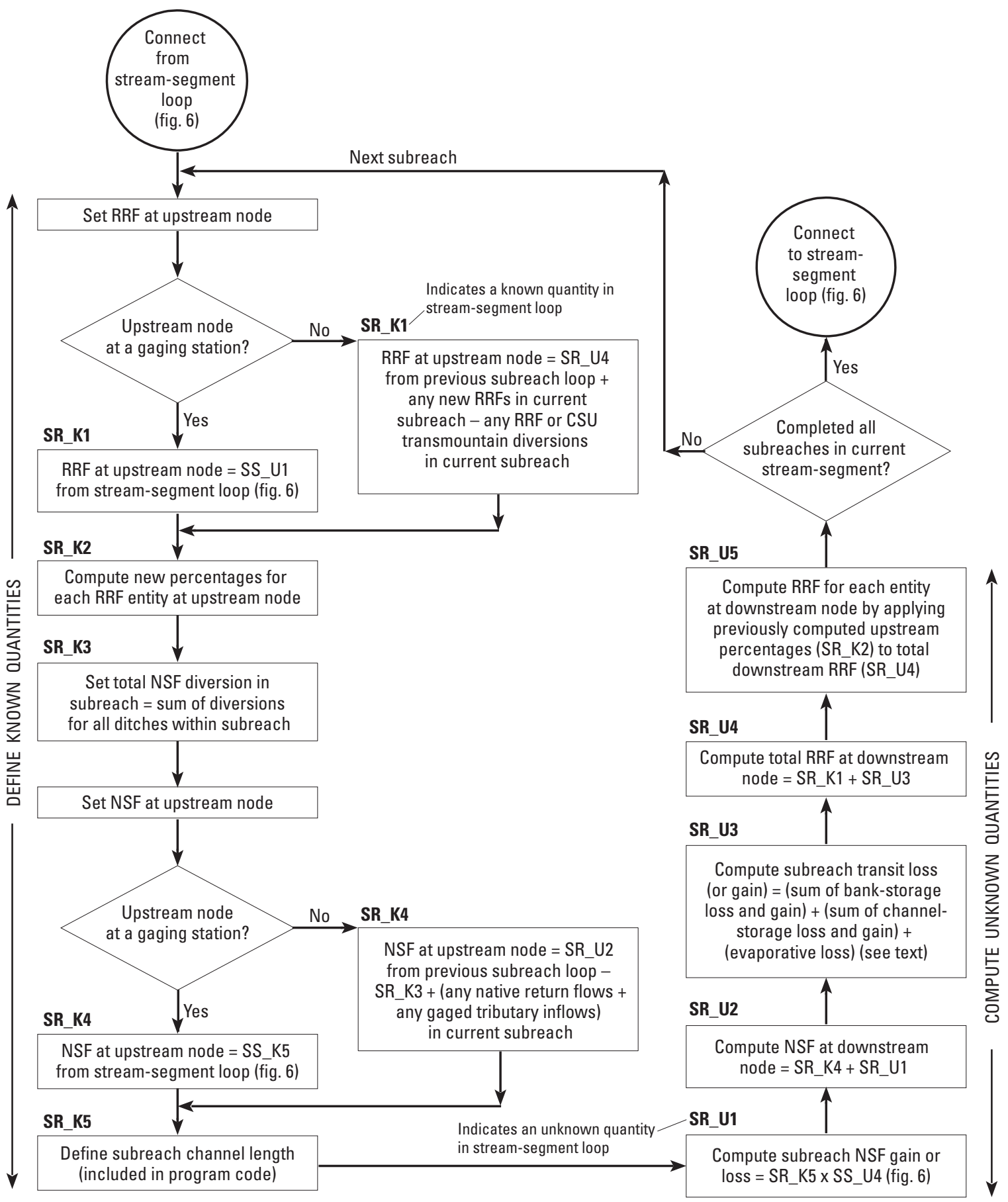

[Note: CSU, Colorado Springs Utilities; NSF, Native streamflow; RRF, Reusable return flow]

Figure 7. Primary computations for subreach loop in new transit-loss accounting program for Monument and Fountain Creeks.

4. SS_K4, which is the total NSF diversion in the current stream segment; the value is derived by summing all NSF diversions in the segment.

5. SS_K5, which is the total NSF at the upstream node that will be used for the estimation of NSF loss or gain in the current stream segment. Total upstream NSF is equal to the upstream station discharge (SS_K1) minus the sum of the RRFs (SS_K3) plus the sum of any native return flows and tributary flows in the current segment.

6. SS_K6, which is the stream channel length, in miles. SS_K6 is derived by summing the channel lengths of all subreaches in the segment. 
The unknown quantities (SS_Ux, where $\mathrm{x}$ is a number) that are computed in the stream-segment loop (fig. 6) are the following:

1. SS_U1, which is the estimated RRF at the downstream node. For the first iteration of the stream-segment loop, SS_U1 is assumed to be equal to SS_K3 (fig. 6); for subsequent iterations, the computed value for downstream RRF from the subreach loop (SR_U5, fig. 7) is used for SS_U1 (also see "Assumptions Used in the Computations" section).

2. SS_U2, which is the conditional (estimated) NSF at the downstream node. SS_U2 is equal to the total discharge at the downstream node (SS_K2) minus the estimated downstream RRF (SS_U1) plus the total NSF diversion in the stream segment (SS_K4). The value for downstream NSF is based on the assumption that NSF diversions in the stream segment had not occurred; therefore, downstream NSF is considered to be conditional.

3. SS_U3, which is the estimated total NSF loss or gain in the stream segment. SS_U3 is equal to the conditional NSF at the downstream node (SS_U2) minus the NSF at the upstream node (SS_K5).

4. SS_U4, which is the estimated stream-segment NSF loss or gain, in cubic feet per second per mile. SS_U4 is equal to the total NSF loss or gain (SS_U3) divided by the stream-segment channel length (SS_K6).

After the first stream-segment iteration, the program shifts to the subreach loop. At the conclusion of the first subreach loop, if the convergence criterion (see "Assumptions Used in the Computations" section) is not met, the streamsegment loop is repeated, but only for that part of the loop in which the unknown downstream quantities are estimated (fig. 6). The subreach loop then is reiterated and the process continues until the convergence criterion is met.

\section{Subreach Computations}

In the subreach computations (fig. 7), the following subreach known quantities (SR_Kx, where $\mathrm{x}$ is a number) need to be defined:

1. SR_K1, which is the RRF at the upstream node. For most subreaches, SR_K1 is equal to RRF at the downstream node (SR_U4) from the previous subreach computation (fig. 7). For a subreach with the upstream node at a gaging station, SR_K1 is equal to RRF at the downstream gaging station (SS_U1) from the previous stream-segment loop (fig. 6).

2. SR_K2, which is the RRF percentage for each individual RRF entity at the upstream node just prior to the transitloss computations for the current subreach.
3. SR K3, which is the total NSF diversion between the nodes. The NSF diversions are input individually for each ditch, and the program sums the diversions for all ditches within the subreach.

4. SR_K4, which is the NSF at the upstream node. For most subreaches, SR_K4 is equal to NSF at the downstream node (SR_U1) from the previous subreach computations (fig. 7). For a subreach with the upstream node at a gaging station, SR_K4 is equal to RRF at the downstream gaging station (SS_U4) from the previous stream-segment loop (fig. 6).

5. SR_K5, which is the subreach channel length, in miles. Values for SR_K4 were determined for application of the stream-aquifer model and are included in the program code.

The unknown quantities (SR_Ux, where $\mathrm{x}$ is a number) that are computed in the subreach loop (fig. 7) are the following:

1. SR_U1, which is the NSF loss or gain in the subreach. SR_U1 is equal to the product of the subreach channel length (SR_K5, fig. 7) times the stream-segment NSF loss or gain per mile (SS_U4, fig. 6).

2. SR_U2, which is the NSF at the downstream node. SR_U2 is equal to the sum of NSF at the upstream node (SR_K4) plus NSF loss or gain in the subreach (SR_U1).

3. SR_U3, which is the net transit loss for the total of all RRFs in the subreach. SR_U3 consists of estimated bankstorage loss, channel-storage loss, and evaporative loss based on the results from applying a stream-aquifer model (Land, 1977) to Monument Creek (Kuhn and Arnold, 2006) and Fountain Creek (Kuhn, 1988).

4. $\quad$ SR_U4, which is the RRF at the downstream node. SR_U4 is equal to the sum of RRF at the upstream node (SR_K1) and the net transit loss for the subreach (SR_U3).

5. SR_U5, which is the RRF at the downstream node for each individual RRF entity. The values of SR_U5 for each RRF entity are computed as the product of the total downstream RRF (SR_U4) times the flow percentage for each entity at the upstream node (SR_K2).

The subreach loop is repeated for each subreach within the stream segment. When computations are completed for all subreaches within a stream segment, the convergence criterion is evaluated. If the criterion is not met, all computations are repeated for the current stream segment and all subreaches in the segment until the convergence criterion is met. Because results of the transit-loss computations are not stored for output until the convergence criterion is met, a final iteration needs to be made in order to output the results. 


\section{Comparison of Results from Existing and New Transit-Loss Accounting Programs}

In order to evaluate the effects, if any, of the change in how transit losses for each individual RRF entity are accounted for in the new accounting program (see the "New Method for Reusable Return-Flow Accounting" section), results from the existing accounting program were compared to results from the new accounting program for water year 2006. The data that were manually entered to the existing accounting program during the course of the year were extracted from the daily output reports (which also list the entered data) and these data then were used for input to the new accounting program.

Results from the output reports for each accounting program (table 3 ) indicate very little difference between the volumes of reusable water delivered by using each of the accounting programs. Although the difference for "Colo. Springs FRY-ARK RetrnFlw at Las Vegas WWTF" seems large (about 12 percent, table 3 ), the relatively short duration of the release period and the release interruption (table 1) affect the difference more than the different accounting methods. Reasons for the -3 percent difference for "Widefield FRY-ARK RetrnFlw at Widefield WWTF" (table 3) are not clearly known, but certainly are no greater than other allowable errors, such as errors in discharge data at gaging stations. The error ( -0.2 percent) for all RRFs is inconsequential (table 3 ). The summing of results for more than one reusable return-flow entity (table 3 ) was necessary because the version of the existing program in use during water year 2006 included some minor revisions to the program that enabled accounting for several new RRFs. The accounting for these new RRFs was not enabled by developing completely new transit-loss computation subroutines (as in previous program revisions), but by enabling a partial implementation of the method for accounting for multiple RRFs that is used in the new accounting program (see the "New Method for Reusable Return-Flow Accounting" section). The results listed in table 3 indicate that the new method for accounting for multiple RRFs is not substantially different than the method used in the existing program, and as previously mentioned, the new method is more similar to the simulation of streamflow in the stream-aquifer modeling (Kuhn and Arnold, 2006; Kuhn, 1988), in which streamflow was divided into two flow components (see the "New Method for Reusable Return-Flow Accounting" section).

Table 3. Input volumes and comparison of delivery volumes for existing and new transit-loss accounting programs for Monument and Fountain Creeks for selected reusable return-flow entities, water year 2006.

\begin{tabular}{|c|c|c|c|c|c|}
\hline \multirow{2}{*}{ Reusable return-flow entity name ${ }^{1}$} & \multirow{2}{*}{$\begin{array}{l}\text { Input volume } \\
\text { (acre-feet) }\end{array}$} & \multicolumn{2}{|c|}{$\begin{array}{l}\text { Delivery volume } \\
\text { (acre-feet) }\end{array}$} & \multirow{2}{*}{$\begin{array}{l}\text { Difference }^{3} \\
\text { (acre-feet) }\end{array}$} & \multirow{2}{*}{$\begin{array}{r}\text { Difference } \\
\text { (percent) }\end{array}$} \\
\hline & & $\begin{array}{l}\text { Existing } \\
\text { program }^{2}\end{array}$ & $\begin{array}{c}\text { New } \\
\text { program }^{2}\end{array}$ & & \\
\hline Fort Carson Transmountain RetrnFlw via Clover Ditch & 549.8 & -- & -- & -- & -- \\
\hline Sum of two above return-flow entities & $29,919.9$ & $27,522.2$ & $27,459.7$ & -62.5 & -0.2 \\
\hline Stratmoor Hills Fry-Ark RetrnFlw at Las Vegas WWTF & 215.3 & -- & -- & -- & -- \\
\hline Security FRY-ARK RetrnFlw at Security WWTF & 90.3 & -- & -- & -- & -- \\
\hline Sum of two above return-flow entities & 305.6 & 285.5 & 289.0 & 3.4 & 1.2 \\
\hline Widefield FRY-ARK RetrnFlw at Widefield WWTF & 868.5 & 826.5 & 801.8 & -24.7 & -3.0 \\
\hline FMIC 2250 Supplemental Flow at Cruse Gulch & 535.4 & -- & -- & -- & -- \\
\hline Widefield Supplemental Flow at Cruse Gulch & 553.9 & -- & -- & -- & -- \\
\hline Sum of five above return-flow entities & $2,290.7$ & $2,039.9$ & $2,054.0$ & 13.8 & 0.7 \\
\hline Sum of all return-flow entities & $33,391.9$ & $30,680.7$ & $30,611.6$ & -69.2 & -0.2 \\
\hline
\end{tabular}

${ }^{1}$ Name as listed in figure $3 B$.

${ }^{2}$ May 11 not included in input or delivery volumes because of missing data.

${ }^{3}$ Volume difference $=($ New program delivery volume - Existing program delivery volume $)$.

${ }^{4}$ Percentage difference $=($ New program delivery volume - Existing program delivery volume $) /($ Existing program delivery volume $\times 100)$. 


\section{Summary}

The U.S. Geological Survey (USGS), in cooperation with Colorado Springs Utilities, the Colorado Water Conservation Board, and the El Paso County Water Authority, began a study in 2004 with the following objectives: (1) Apply a streamaquifer model to Monument Creek, (2) use the results of the modeling to develop a transit-loss accounting program for Monument Creek, (3) revise an existing accounting program for Fountain Creek to easily incorporate ongoing and future changes in management of return flows of reusable water, and (4) integrate the two accounting programs into a single program with a Web-based interface that incorporates simple and reliable data input that is automated to the fullest extent possible. This report describes the results of completing objectives (2), (3), and (4) of that study.

The first step in developing the transit-loss accounting program for Monument and Fountain Creeks was to develop an accounting program for Monument Creek by (1) using the existing program for Fountain Creek as a prototype; (2) incorporating the transit-loss results from applying the stream-aquifer model to Monument Creek into the subroutines that compute the transit losses; and (3) developing new output reports. The second step of the process was to expand the capability of the new input routines to read additional input data for the Fountain Creek reach (the existing program), modify the transit-loss accounting subroutines to include the input data for Fountain Creek, and include transit-loss accounting results for Fountain Creek in the new output reports. The last step of the process was to develop the Web-based interface for the new transit-loss accounting program. An integrated system of 34 nodes and 33 subreaches was developed by combining the independent node and subreach systems used in the previously completed stream-aquifer modeling studies for the Monument and Fountain Creek reaches.

A number of operational requirements for the integrated transit-loss accounting program for Monument and Fountain Creeks were attained, which included: (1) Retain all the reusable water-management capabilities incorporated into the existing accounting program for Fountain Creek; (2) enable daily accounting and transit-loss computations for any number of reusable return flows discharged into Monument Creek at selected locations; (3) enable diversion (removal from the transit-loss accounting program and transit-loss computations) of all or a part of a reusable return flow at any selected node for purposes of storage in off-stream reservoirs or other types of reusable water management; (4) provide flexibility in the accounting program to change the number of returnflow entities, the location node where a return flow may be input to the system, and the node to where a return flow is to be delivered; and (5) develop a Web-based interface to the accounting program.

A flexible data-input method was developed for the accounting program in which a single data file would interact with both the Web-based user interface and the FORTRANbased accounting program. The primary feature of the input file is the use of blank data lines that serve as placeholders for possible future inputs to the accounting program. In the accounting program, the data fields in the input file are read into arrays, which allow the dimension sizes to be changed easily.

Both the existing and the new transit-loss accounting programs were developed and are maintained by personnel in the USGS Colorado Water Science Center, including all the numerous input and output files used by the programs. Daily operation of the program, however, is made by the Colorado Division of Water Resources District 10 Water Commissioners, who, in conjunction with the Colorado Division of Water Resources District Engineer, administer water rights along Monument and Fountain Creeks. Access to the Web-based interface to the transit-loss accounting program is made through a password-controlled login. Each reusable return-flow management entity will be able to login to the data-entry form for purposes of entering data; however, only the Colorado Division of Water Resources District 10 Water Commissioners will have authority to actually run the accounting program.

The primary component of the Web-based interface is a data-entry form that displays data from the accounting program input file and allows for changes and input of new data. When the data-entry form is displayed, up-to-date discharge data for each station are automatically computed from the USGS National Water Information System and entered on the data-entry form. Native return-flow data, reusable return-flow data, reusable return-flow diversion data, and native diversion data at the ditches along Monument and Fountain Creeks are input on the data-entry form.

At the conclusion of each daily run of the transit-loss accounting program, a multipage output report is written that contains all of the input data for that date, as well as results of the transit-loss computations. The output report includes (1) input data for gaging stations and native return flows, (2) input data for all reusable return flows and reusable returnflow diversions; (3) a summary of reusable return flows, reusable and transmountain diversions, and transit losses for each subreach along Monument and Fountain Creeks; (4) a summary of native flows, tributary inflows, native return flows, native diversions, and gains and losses in native discharge for each subreach along Monument and Fountain Creeks.

In computing the estimated quantities of reusable return flow and the associated transit losses, the accounting program uses two sets of computations. The first set of computations is made between any two adjacent gaging stations (streamsegment loop); the primary purpose of the stream-segment loop is to estimate the loss or gain in native discharge between the two adjacent gaging stations. The second set of computations is made between any two adjacent nodes (subreach loop); the actual transit-loss computations are made in the subreach loop, using the result from the stream-segment loop. The stream-segment loop is completed for a stream segment, and then the subreach loop is completed for each subreach within the segment. When the subreach loop is completed for 
all subreaches within a stream segment, the stream-segment loop is initiated for the next stream segment, followed again by initiating the subreach loop; the process continues until transit-loss computations are completed downstream through all subreaches.

To compute estimated transit losses using the accounting program, an assumption must be made in the stream-segment loop that the quantity of reusable return flow at the downstream gaging station initially is the same as at the upstream station. This assumption is necessary because, at this point in the computations, the quantity of reusable return flow at the downstream station is not known. The computed reusable return-flow at the downstream node of the stream segment always will be different from the assumed downstream return flow. An iterative process then begins in which the streamsegment loop is repeated, including all subreach computations within the stream segment. In each repeated iteration, the previously computed downstream reusable return flow is used for the new assumed downstream reusable return flow. When the difference between the assumed and computed values is less than 0.01 cubic feet per second, the program moves to the next stream segment. Results from the existing accounting program were compared with results from the new accounting program for water year 2006. The comparison indicated that results from the new accounting program are not substantially different from the results of the old accounting program.

\section{References Cited}

Flynn, K.M., Kittle, J.L., Jr., and Lumb, A.M., 1994, A Fortran coding convention for use in the U.S. Geological Survey Water Resources Division: U.S. Geological Survey Open-File Report 94-501, 64 p.

Kuhn, Gerhard, 1988, Methods to determine transit losses for return flows of transmountain water in Fountain Creek between Colorado Springs and the Arkansas River, Colorado: U.S. Geological Survey Water-Resources Investigations Report 87-4119, 183 p.
Kuhn, Gerhard, 1991, Calibration, verification, and use of a steady-state stream water-quality model for Monument and Fountain Creeks, east-central Colorado: U.S. Geological Survey Water-Resources Investigations Report 91-4055, 149 p.

Kuhn, Gerhard, and Arnold, L.R., 2006, Application of a stream-aquifer model to Monument Creek for development of a method to estimate transit losses for reusable water, El Paso County, Colorado: U.S. Geological Survey Scientific Investigations Report 2006-5184, 111 p.

Kuhn, Gerhard, Samuels, E.L., Bemis, W.D., and Steger, R.D., 1998, Description of the program changes (1989-97) and a user manual for a transit loss accounting program applied to Fountain Creek between Colorado Springs and the Arkansas River, Colorado: U.S. Geological Survey OpenFile Report 97-637, 39 p.

Land, L.E., 1977, Streamflow routing with losses to bank storage or wells: U.S. Geological Survey Computer Contribution, 117 p. [Available from National Technical Information Service, Springfield, VA 22161 as NTIS Report PB-271 535/AS.]

Radosevich, G.E., Nobe, K.C., Allardice, D., and Kirkwood, C., 1976, Evolution and administration of Colorado water law-1876-1976: Fort Collins, Colo., Water Resources Publications, $280 \mathrm{p}$.

Robson, S.G., 1987, Bedrock aquifers in the Denver Basin, Colorado-A quantitative water-resources appraisal: U.S. Geological Survey Professional Paper 1257, 73 p., 5 plates.

Waskom, Reagan, and Neibauer, M., 2004, Glossary of water terminology: Colorado State University Cooperative Extension, Water Resource Fact Sheet 4.717, accessed May 16, 2006, at http://www.ext.colostate.edu/pubs/crops/04717.html 



\section{Appendixes}



Appendix 1. Example of data input file for new transit-loss accounting program for Monument and Fountain Creeks.

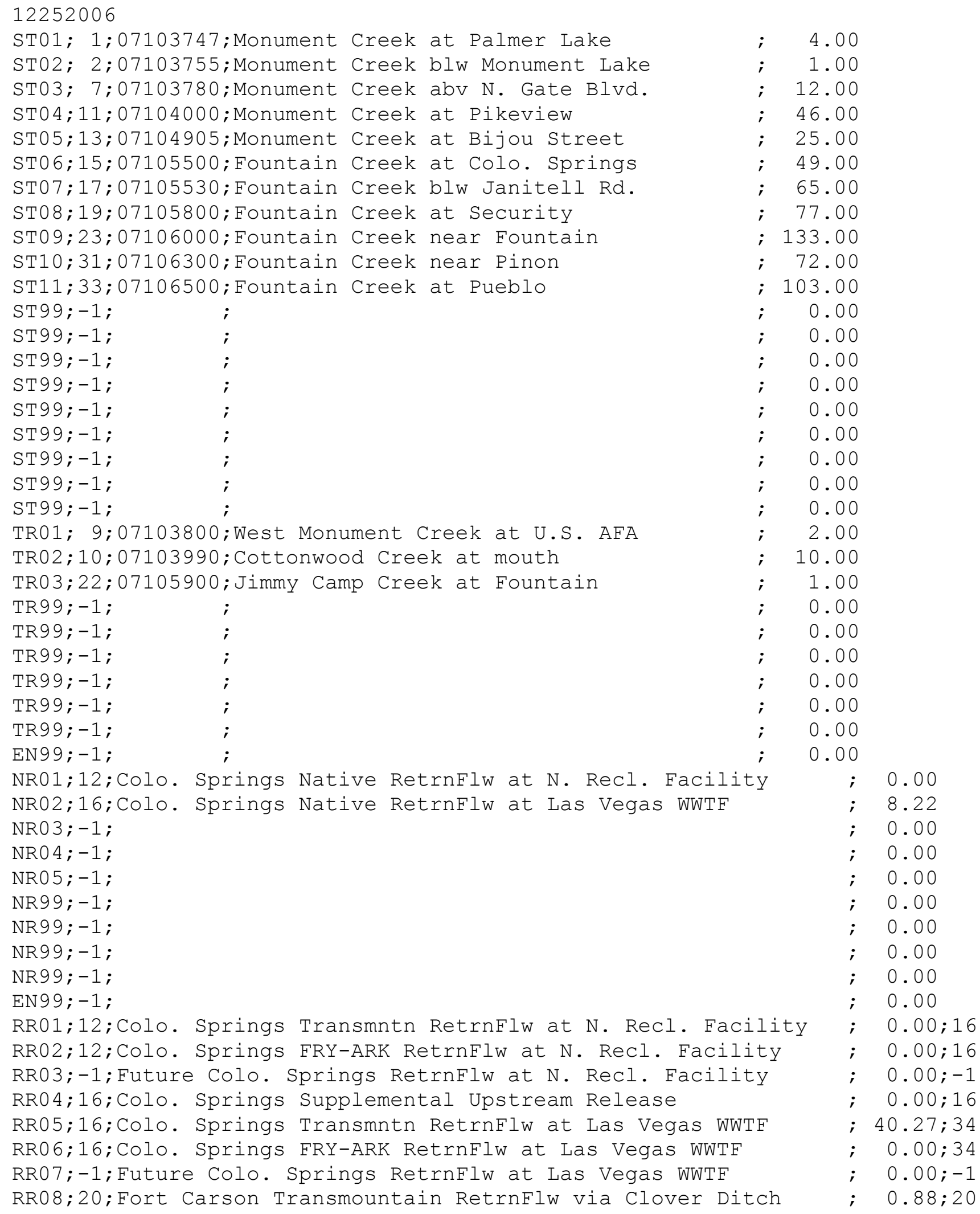


Appendix 1. Example of data input file for new transit-loss accounting program for Monument and Fountain Creeks—Continued.

\begin{tabular}{|c|c|c|}
\hline RR09;-1; Monument1 Den. Basin RetrnFlw at Tri-Lakes WWTF & ; & $0.00 ;-1$ \\
\hline RR10;-1; Monument2 Den. Basin RetrnFlw at Tri-Lakes WWTF & & $0.00 ;-1$ \\
\hline RR11;-1; Monument3 Den. Basin RetrnFlw at Tri-Lakes WWTF & & $0.00 ;-1$ \\
\hline RR12;-1; Palmer Lk1 Den. Basin RetrnFlw at Tri-Lakes WWTF & 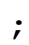 & $0.00 ;-1$ \\
\hline R13;-1;Palmer Lk2 Den. Basin RetrnFlw at Tri-Lakes WWTF & & $0 ;-1$ \\
\hline R14;-1; Palmer Lk3 Den. Basin RetrnFlw at Tri-Lakes WWTF & & $00 ;-1$ \\
\hline RR15;-1; Woodmoor1 Den. Basin RetrnFlw at Tri-Lakes WWTF & & $0.00 ;-1$ \\
\hline RR16;-1; Woodmoor2 Den. Basin RetrnFlw at Tri-Lakes WWTF & & $0.00 ;-1$ \\
\hline RR17;-1;Woodmoor3 Den. Basin RetrnFlw at Tri-Lakes WWTF & & $0.00 ;-1$ \\
\hline RR18;-1; Donalal Den. Basin RetrnFlw at Upr. Mon. Regional WWTF & & $0.00 ;-1$ \\
\hline RR19;-1; Donala2 Den. Basin RetrnFlw at Upr. Mon. Regional Wh & & $;-1$ \\
\hline RR20;-1; Donala3 Den. Basin RetrnFlw at Upr. Mon. Regional WWTF & & $;-1$ \\
\hline RR21;-1; ForestLks1 Den. Bsn RetrnFlw at Upr. Mon. Regional WWTF & & $0.00 ;-1$ \\
\hline RR22;-1;Forestlks2 Den. Bsn RetrnFlw at Upr. Mon. Regional WWTF & & $0.00 ;-1$ \\
\hline RR23;-1; Forestlks3 Den. Bsn RetrnFlw at Upr. Mon. Regional WWTF & & $;-1$ \\
\hline RR24;-1;Triview1 Den. Basin RetrnFlw at Upr. Mon. Regional WWTF & & $;-1$ \\
\hline RR25;-1;Triview2 Den. Basin RetrnFlw at Upr. Mon. Regional WWTF & & ; -1 \\
\hline RR26;-1;Triview3 Den. Basin RetrnFlw at Upr. Mon. Regional WWTF & & $0.00 ;-1$ \\
\hline RR27;16; Stratmoor Hills Fry-Ark RetrnFlw at Las Vegas WWTF & $i$ & ; 34 \\
\hline RR28; 19; Security FRY-ARK RetrnFlw at Security WWTF & & \\
\hline 9;19; Widefield FRY-ARK RetrnFlw at Widefield WWTF & & 34 \\
\hline ; 19; Fountain FRY-ARK RetrnFlw at Widefield WWTF & & 34 \\
\hline 1;19; Fountain Supplemental Flow at Cruse Gulch & & 0. \\
\hline 2;19; Widefield Supplemental Flow at Cruse Gulch & & 0.0 \\
\hline 3;19; FMIC 2250 Supplemental Flow at Cruse Gulch & & 0. \\
\hline 4;23; Fountain FRY-ARK RetrnFlw at Fountain WWTF & & 0 . \\
\hline$;-1 ;$ & & \\
\hline 1 ; & & ; -1 \\
\hline$;-1 ;$ & & $;-1$ \\
\hline$;-1 ;$ & & $;-1$ \\
\hline$;-1 ;$ & & \\
\hline ; $-1 ;$ & & -1 \\
\hline$;-1 ;$ & & 0.0 \\
\hline$;-1 ;$ & & $;-1$ \\
\hline$;-1 ;$ & & $;-1$ \\
\hline$;-1 ;$ & & -1 \\
\hline$;-1 ;$ & & -1 \\
\hline ; $-1 ;$ & & $;-1$ \\
\hline$;-1 ;$ & & $;-1$ \\
\hline$;-1 ;$ & & ; -1 \\
\hline$;-1 ;$ & & ; -1 \\
\hline$;-1 ;$ & & ; -1 \\
\hline ; 16; Diversion for storage of CS transmountain at FM Canal & & ; 5 \\
\hline ;20; Diversion for storage of CS transmountain at Chilcotte & & ; 5 \\
\hline 3;16; Diversion for storage of CS FRY-ARK at FM Canal & & ; 6 \\
\hline RO04;20; Diversion for storage of CS FRY-ARK at Chilcotte & & $0.00 ; 6$ \\
\hline 5;10; Divrsion1 of Monument return flow at unknown location & & $0.00 ; 9$ \\
\hline ; 14; Divrsion2 of Monument return flow at unknown location & & $0.00 ; 10$ \\
\hline$;-1 ;$ & & $0.00 ;-1$ \\
\hline$;-1 ;$ & & $;-1$ \\
\hline$;-1 ;$ & & $;-1$ \\
\hline$;-1 ;$ & & $0.00 ;-1$ \\
\hline ; -1 ; & & $0.00 ;-1$ \\
\hline
\end{tabular}


Appendix 1. Example of data input file for new transit-loss accounting program for Monument and Fountain Creeks—Continued.

\begin{tabular}{|c|c|c|c|c|c|}
\hline \multicolumn{6}{|l|}{ RO99; $-1 ;$} \\
\hline \multicolumn{6}{|l|}{ RO99; $-1 ;$} \\
\hline \multicolumn{6}{|l|}{ RO99; -1; } \\
\hline \multicolumn{6}{|l|}{$\mathrm{RO99;}-1 ;$} \\
\hline \multicolumn{6}{|l|}{$\mathrm{RO99} ;-1 ;$} \\
\hline \multicolumn{6}{|l|}{$\mathrm{RO99} ;-1 ;$} \\
\hline \multicolumn{6}{|l|}{$\mathrm{RO99} ;-1 ;$} \\
\hline \multicolumn{6}{|l|}{$\mathrm{RO99;}-1 ;$} \\
\hline \multicolumn{6}{|l|}{ EN99; $-1 ;$} \\
\hline MD01; 4 ; Monument No. 2 & ; & 0.00 & & & \\
\hline MD02;12;Pikeview diversn & & 0.00 & & & \\
\hline MD99;-1; & ; & 0.00 & & & \\
\hline $\operatorname{MD} 99 ;-1 ;$ & ; & 0.00 & & & \\
\hline EN99; $-1 ;$ & ; & 0.00 & & & \\
\hline FDO1;16; Fountain Mutual & ; & $44.60 ;$ & $0.00 ;$ & $0.00 ;$ & 0.00 \\
\hline FD02;17; Laughlin & ; & $0.00 ;$ & $0.00 ;$ & $0.00 ;$ & 0.00 \\
\hline FD03;18; Stubbs \& Miller & ; & $0.00 ;$ & 0.00 & $0.00 ;$ & 0.00 \\
\hline FD0 $4 ; 20 ;$ Chilcotte & ; & $0.00 ;$ & $0.00 ;$ & $0.00 ;$ & 0.00 \\
\hline FD05;20;Crabb & ; & $0.00 ;$ & 0.00 & $0.00 ;$ & 0.00 \\
\hline FD0 $6 ; 20 ;$ Liston \& Love N. & & $0.00 ;$ & 0.00 & $0.00 ;$ & 0.00 \\
\hline FD07;20; Liston \& Love S. & & $0.00 ;$ & 0.00 & $0.00 ;$ & 0.00 \\
\hline FD0 $8 ; 20 ;$ Lock & ; & $0.00 ;$ & 0.00 & $0.00 ;$ & 0.00 \\
\hline FD09;20;Miller & ; & $0.00 ;$ & 0.00 ; & $0.00 ;$ & 0.00 \\
\hline FD10;25; Owen \& Hall & ; & $0.00 ;$ & $0.00 ;$ & $0.00 ;$ & 0.00 \\
\hline FD11;25;Talcott \& Cotton & & $0.00 ;$ & $0.00 ;$ & $0.00 ;$ & 0.00 \\
\hline FD12;26;Tom Wanless & ; & $0.00 ;$ & 0.00 & $0.00 ;$ & 0.00 \\
\hline FD13;26;Robinson & ; & $0.00 ;$ & $0.00 ;$ & $0.00 ;$ & 0.00 \\
\hline FD14;28;Dr. Rogers & ; & 1.47; & 0.00 & $0.00 ;$ & 0.00 \\
\hline FD15;28;Burke & ; & $0.00 ;$ & $0.00 ;$ & $0.00 ;$ & 0.00 \\
\hline FD16;29;Toof \& Harmon & ; & $0.00 ;$ & $0.00 ;$ & $0.00 ;$ & 0.00 \\
\hline FD17;29; Wood Valley & ; & $0.00 ;$ & 0.00 & $0.00 ;$ & 0.00 \\
\hline FD18;29;Bannister & ; & $0.00 ;$ & 0.00 ; & $0.00 ;$ & 0.00 \\
\hline ED19; 30; Lincoln & ; & $0.00 ;$ & 0.00 & $0.00 ;$ & 0.00 \\
\hline FD20;31; Sutherland & ; & $0.00 ;$ & $0.00 ;$ & $0.00 ;$ & 0.00 \\
\hline FD21;31; Benesch & ; & $0.00 ;$ & $0.00 ;$ & $0.00 ;$ & 0.00 \\
\hline FD22;31;Cawlfield & ; & $0.00 ;$ & 0.00 & $0.00 ;$ & 0.00 \\
\hline FD23;32;H.R. Steele & ; & $0.00 ;$ & 0.00 ; & $0.00 ;$ & 0.00 \\
\hline FD24;32;M.W. Steele & ; & $0.00 ;$ & 0.00 & $0.00 ;$ & 0.00 \\
\hline FD25;32; Greenview & ; & $0.00 ;$ & $0.00 ;$ & $0.00 ;$ & 0.00 \\
\hline FD26;32;Olin & ; & $0.00 ;$ & 0.00 & $0.00 ;$ & 0.00 \\
\hline FD27;32; Cactus & ; & $0.00 ;$ & 0.00 & $0.00 ;$ & 0.00 \\
\hline FD99;-1; & ; & $0.00 ;$ & 0.00 ; & $0.00 ;$ & 0.00 \\
\hline FD99; $-1 ;$ & ; & $0.00 ;$ & $0.00 ;$ & $0.00 ;$ & 0.00 \\
\hline EN99; -1; & ; & $0.00 ;$ & 0.00 ; & $0.00 ;$ & 0.00 \\
\hline
\end{tabular}

$\begin{array}{ll}; & 0.00 ;-1 \\ ; & 0.00 ;-1 \\ ; & 0.00 ;-1 \\ ; & 0.00 ;-1 \\ ; & 0.00 ;-1 \\ ; & 0.00 ;-1 \\ ; & 0.00 ;-1 \\ ; & 0.00 ;-1 \\ ; & 0.00 ;-1\end{array}$

$0.00 ;-1$

$00 ;-1$ 
Appendix 2. Example of output report from new transit-loss accounting program for Monument and Fountain Creeks.

MONUMENT AND FOUNTAIN CREEKS TRANSIT LOSS COMPUTATIONS FOR RELEASE DATE: 12-25-2006 (Page 1/7)

\begin{tabular}{|c|c|c|c|}
\hline NUMBER & NAME & DISCHARGE & $\begin{array}{l}\text { INPUT } \\
\text { NODE }\end{array}$ \\
\hline 07103747 & Monument Creek at Palmer Lake & 4.00 & 1 \\
\hline 07103755 & Monument Creek blw Monument Lake & 1.00 & 2 \\
\hline 07103780 & Monument Creek abv N. Gate Blvd. & 12.00 & 7 \\
\hline 07104000 & Monument Creek at Pikeview & 46.00 & 11 \\
\hline 07104905 & Monument Creek at Bijou Street & 25.00 & 13 \\
\hline 07105500 & Fountain Creek at Colo. Springs & 49.00 & 15 \\
\hline 07105530 & Fountain Creek blw Janitell Rd. & 65.00 & 17 \\
\hline 07105800 & Fountain Creek at Security & 77.00 & 19 \\
\hline 07106000 & Fountain Creek near Fountain & 133.00 & 23 \\
\hline 07106300 & Fountain Creek near Pinon & 72.00 & 31 \\
\hline 07106500 & Fountain Creek at Pueblo & 103.00 & 33 \\
\hline 07103800 & West Monument Creek at U.S. AFA & 2.00 & 9 \\
\hline 07103990 & Cottonwood Creek at mouth & 10.00 & 10 \\
\hline 07105900 & Jimmy Camp Creek at Fountain & 1.00 & 22 \\
\hline
\end{tabular}

REPORTED NATIVE RETURN FLOWS, IN CFS

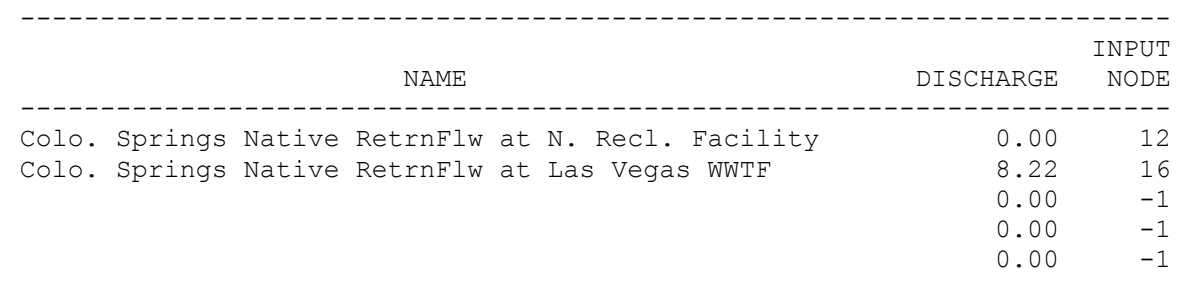

\begin{tabular}{|c|c|c|}
\hline $\begin{array}{c}\text { NODE } \\
\text { NUMBER }\end{array}$ & $\begin{array}{l}\text { RIVER } \\
\text { MILE }\end{array}$ & NODE DESCRIPTION \\
\hline \multirow{2}{*}{\multicolumn{3}{|c|}{ MONUMENT CREEK REACH }} \\
\hline & & \\
\hline$\frac{1}{2}$ & 1.0 & At station 07103747 \\
\hline 2 & & At station 07103755 \\
\hline 3 & 1.8 & At Dirty Woman Creek \\
\hline 4 & 2.8 & At Tri-Lakes WWTF \\
\hline 5 & 4.8 & At Beaver Creek \\
\hline 6 & 6.3 & At Up. Monument Regl. WWTF \\
\hline 7 & 7.8 & At station 07103780 \\
\hline 8 & 13.3 & At U.S. Air Force Acad. WWTF \\
\hline 9 & 15.1 & At West Monument Creek \\
\hline 10 & 18.3 & At Cottonwood Creek \\
\hline 11 & 19.1 & At station 07104000 \\
\hline 12 & 21.4 & At N. Water Recl. Facility \\
\hline 13 & 25.6 & At station 07104905 \\
\hline 14 & 26.3 & At Cnfl. with Fountain Creek \\
\hline 15 & 27.6 & FntnCrk. at station 07105500 \\
\hline \multicolumn{3}{|c|}{ FOUNTAIN CREEK REACH } \\
\hline 15 & 27.6 & At station 07105500 \\
\hline 16 & 28.2 & At Las Vegas Street WWTF \\
\hline 17 & 29.9 & At station 07105530 \\
\hline 18 & 32.3 & At Stubbs and Miller Ditch \\
\hline 19 & 36.8 & At station 07105800 \\
\hline 20 & 38.1 & At Chilcotte Ditch \\
\hline 21 & 41.5 & At Lock Ditch \\
\hline 22 & 42.3 & At Jimmy Camp Creek \\
\hline 23 & 44.4 & At Owen and Hall Ditch \\
\hline 24 & 47.6 & At Little Fountain Creek \\
\hline 25 & 48.3 & At station 07106000 \\
\hline 26 & 51.3 & At Robinson Ditch \\
\hline 27 & 52.6 & At Williams Creek \\
\hline 28 & 53.8 & At Burke Ditch \\
\hline 29 & 57.2 & At Wood Valley Ditch \\
\hline 30 & 61.1 & At Sutherland Ditch \\
\hline 31 & 63.6 & At station 07106300 \\
\hline 32 & 67.3 & At Greenview Ditch \\
\hline 33 & 75.9 & At station 07106500 \\
\hline 34 & 78.3 & At mouth (Sta. FOUMOUCO) \\
\hline
\end{tabular}


Appendix 2. Example of output report from new transit-loss accounting program for Monument and Fountain Creeks—Continued.

MONUMENT AND FOUNTAIN CREEKS TRANSIT LOSS COMPUTATIONS FOR RELEASE DATE: 12-25-2006 (Page 2/7)

REUSABLE (INCL. TRANSMOUNTAIN) INPUT AND DELIVERD RETURN FLOWS, IN CFS

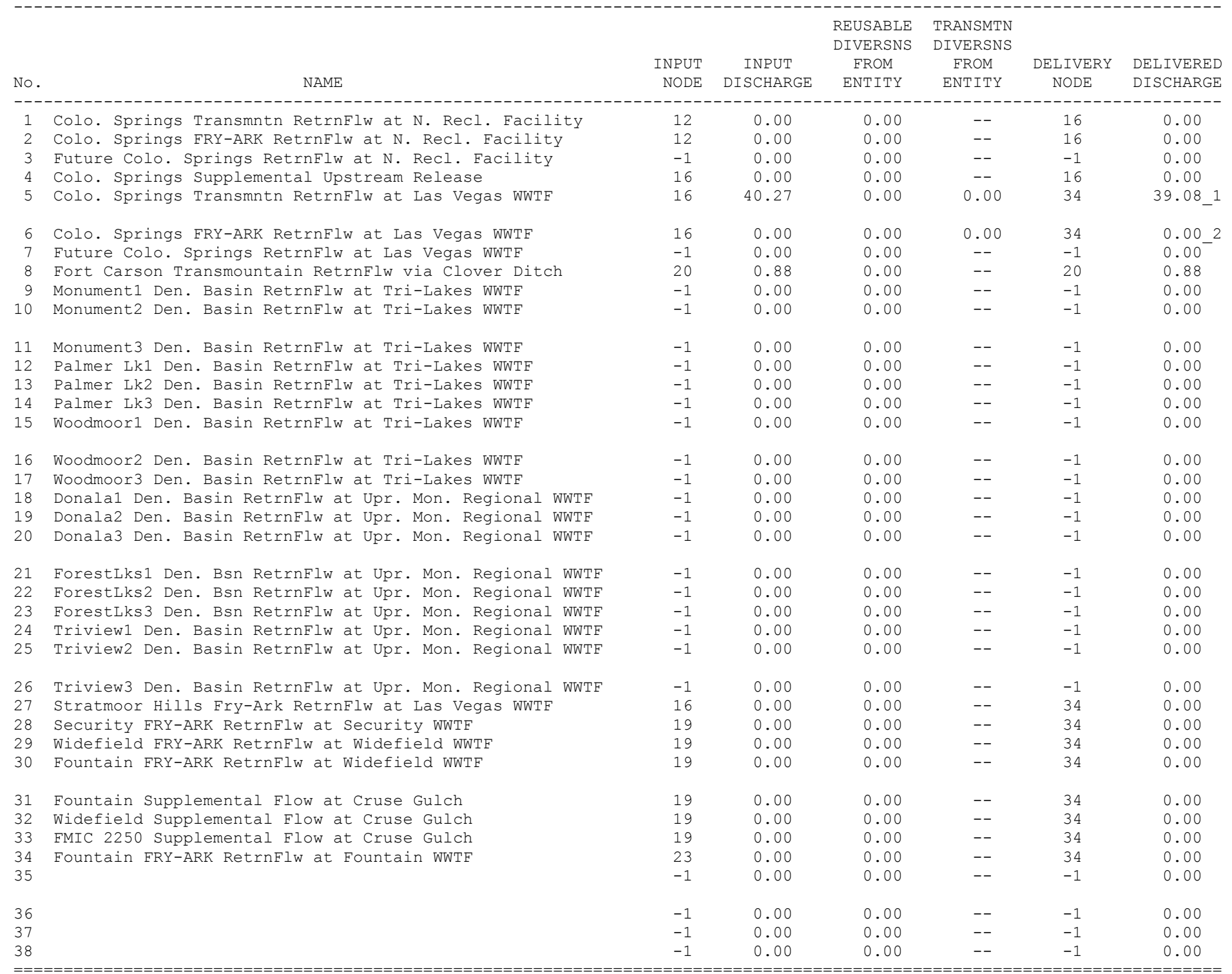

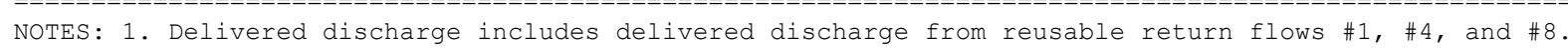

2. Delivered discharge includes delivered discharge from reusable return flow \#2. 
Appendix 2. Example of output report from new transit-loss accounting program for Monument and Fountain CreeksContinued.

MONUMENT AND FOUNTAIN CREEKS TRANSIT LOSS COMPUTATIONS FOR RELEASE DATE: 12-25-2006 (Page 3/7)

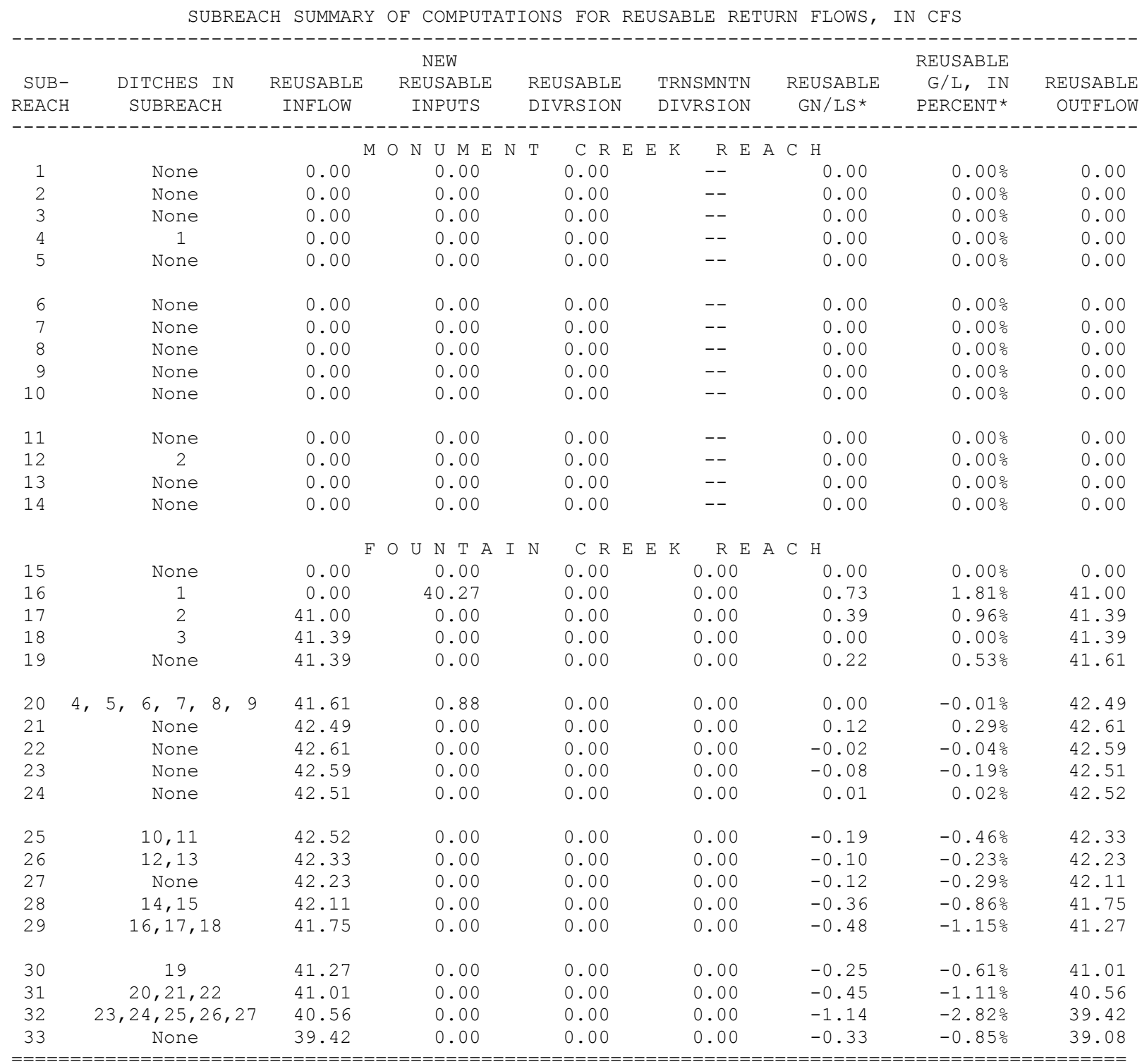

NOTE: * Reusable gain/loss and percentages computed after subreach adjustments to "REUSABLE INFLOW." 
Appendix 2. Example of output report from new transit-loss accounting program for Monument and Fountain Creeks-Continued.

MONUMENT AND FOUNTAIN CREEKS TRANSIT LOSS COMPUTATIONS FOR RELEASE DATE: 12-25-2006 (Page 4/7)

SUBREACH SUMMARY OF COMPUTATIONS FOR NATIVE FLOWS, IN CFS

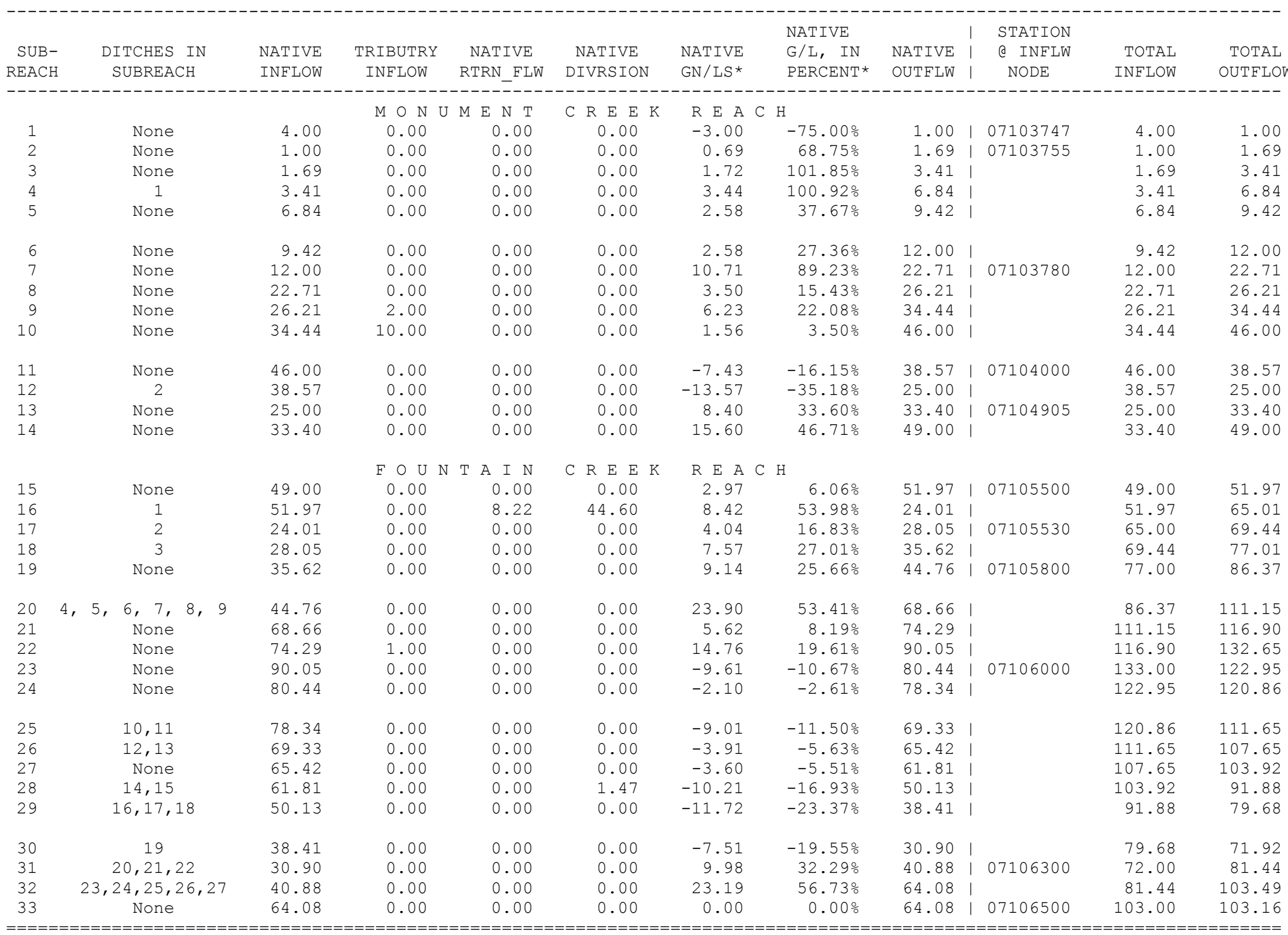

NOTE: * Native gain/loss and percentages computed after subreach adjustments to "NATIVE INFLOW." 
Appendix 2. Example of output report from new transit-loss accounting program for Monument and Fountain CreeksContinued.

MONUMENT AND FOUNTAIN CREEKS TRANSIT LOSS COMPUTATIONS FOR RELEASE DATE: 12-25-2006 (Page 5/7)

NATIVE AND TRANSMOUNTAIN DIVERSIONS AND CALCULATED DIVERSION RELEASES* FOR COLORADO SPRINGS TRANSMOUNTAIN RETURN FLOWS, IN CFS

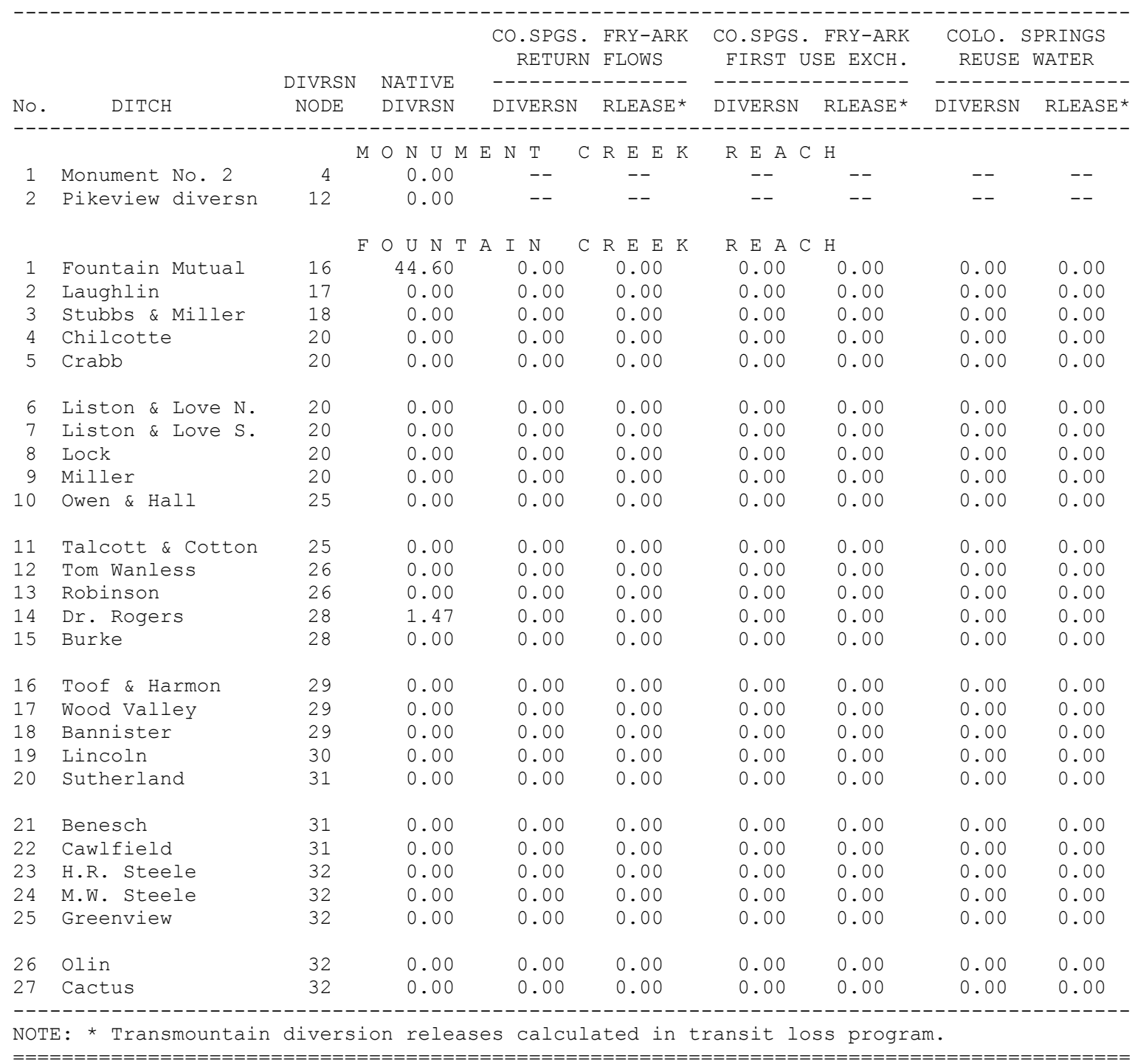


Appendix 2. Example of output report from new transit-loss accounting program for Monument and Fountain CreeksContinued.

MONUMENT AND FOUNTAIN CREEKS TRANSIT LOSS COMPUTATIONS FOR RELEASE DATE: 12-25-2006 (Page 6/7)

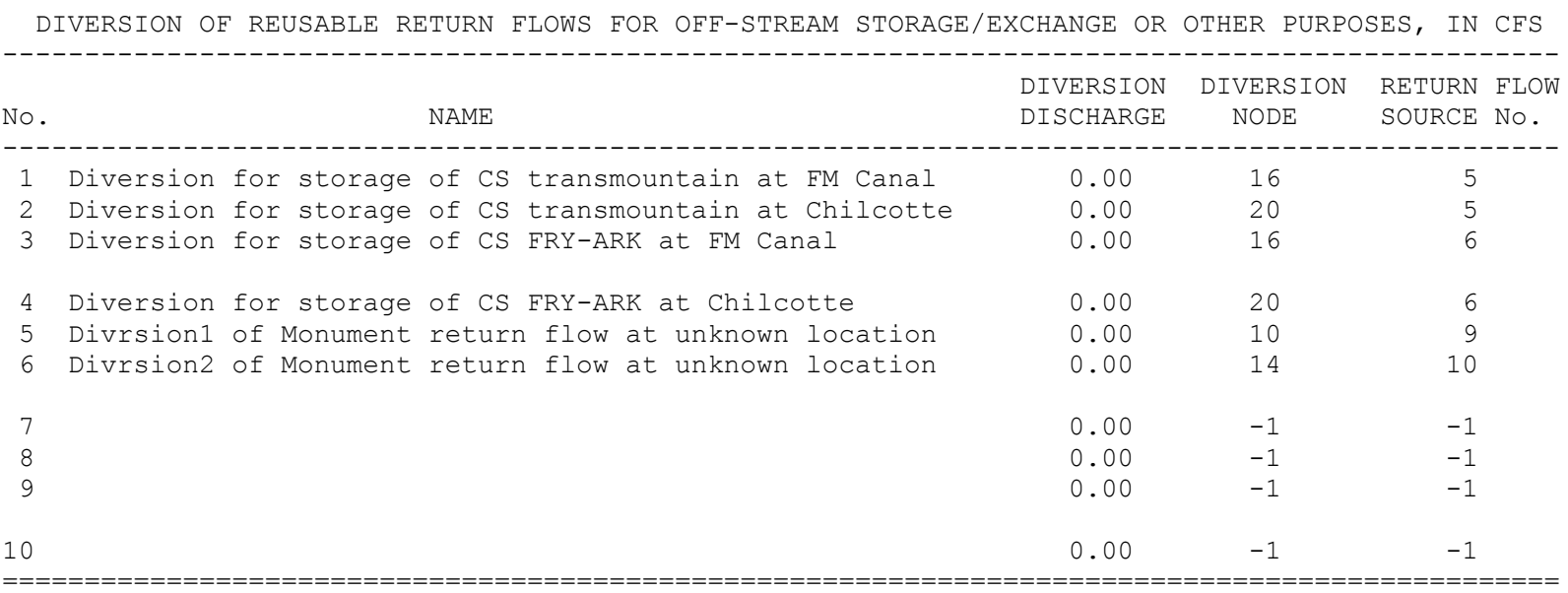

Remarks to ouput report for RELEASE DATE: 12-25-2006, EXCHANGE DATE: 12-26-2006

NONE 
Appendix 2. Example of output report from new transit-loss accounting program for Monument and Fountain Creeks-Continued.

MONUMENT AND FOUNTAIN CREERS TRANSIT LOSS COMPUTATIONS FOR RELEASE DATE: 12-25-2006 (Page 7/7)

\begin{tabular}{|c|c|c|c|c|c|c|c|}
\hline \multirow[b]{2}{*}{ No. } & \multirow[b]{2}{*}{ NAME } & \multicolumn{2}{|c|}{ DAILY VOLUME } & \multicolumn{2}{|c|}{ MONTHLY VOLUME } & \multicolumn{2}{|c|}{ ANNUAL VOLUME* } \\
\hline & & $\mathrm{ACRE}-\mathrm{FT}$ & PERCENT & $\mathrm{ACRE}-\mathrm{FT}$ & PERCENT & ACRE-FT & PERCENT \\
\hline & 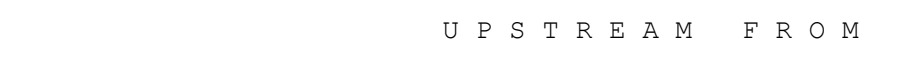 & I $K E \quad E \quad I \quad E$ & W $\quad \mathrm{S} T$ & A $\mathrm{T} I O \mathrm{~N}$ & & & \\
\hline & UPSTREAM TOTALS: & 0.00 & & 0.00 & & 0.00 & \\
\hline & $D \circ W N S T R E A M \quad F R \circ M$ & P I K E V I & $\mathrm{E} W \mathrm{~S}$ & A $T$ T $O \mathrm{~N}$ & & & \\
\hline 1 & Colo. Springs Transmntn Retrnflw at N. Recl. Facility & 0.00 & $0.00 \%$ & 0.00 & $0.00 \%$ & 0.00 & $0.00 \%$ \\
\hline 2 & Colo. Springs FRY-ARK RetrnFlw at N. Recl. Facility & 0.00 & $0.00 \%$ & 0.00 & $0.00 \%$ & 0.00 & $0.00 \%$ \\
\hline 4 & Colo. Springs Supplemental Upstream Release & 0.00 & $0.00 \%$ & 0.00 & $0.00 \%$ & 0.00 & $0.00 \%$ \\
\hline 5 & Colo. Springs Transmntn RetrnFlw at Las Vegas WWTF & 79.88 & $97.86 \%$ & 1903.30 & $98.02 \%$ & 6211.01 & $90.99 \%$ \\
\hline 6 & Colo. Springs FRY-ARK RetrnFlw at Las Vegas WWTF & 0.00 & $0.00 \%$ & 0.00 & $0.00 \%$ & 0.00 & $0.00 \%$ \\
\hline 8 & Fort Carson Transmountain Retrnflw via Clover Ditch & 1.75 & $2.14 \%$ & 38.39 & $1.98 \%$ & 132.35 & $1.94 \%$ \\
\hline 27 & Stratmoor Hills Fry-Ark Retrnflw at Las Vegas WWTF & 0.00 & $0.00 \%$ & 0.00 & $0.00 \%$ & 42.51 & $0.62 \%$ \\
\hline 28 & Security FRY-ARK RetrnFlw at Security WWTF & 0.00 & $0.00 \%$ & 0.00 & $0.00 \%$ & 33.35 & $0.49 \%$ \\
\hline 29 & Widefield FRY-ARK RetrnFlW at Widefield WWTF & 0.00 & $0.00 \%$ & 0.00 & $0.00 \%$ & 214.05 & $3.14 \%$ \\
\hline 30 & Fountain FRY-ARK RetrnFlw at Widefield WWTF & 0.00 & $0.00 \%$ & 0.00 & $0.00 \%$ & 0.00 & $0.00 \%$ \\
\hline 31 & Fountain Supplemental Flow at Cruse Gulch & 0.00 & $0.00 \%$ & 0.00 & $0.00 \%$ & 7.81 & $0.11 \%$ \\
\hline 32 & Widefield Supplemental Flow at Cruse Gulch & 0.00 & $0.00 \%$ & 0.00 & $0.00 \%$ & 68.77 & $1.01 \%$ \\
\hline 33 & FMIC 2250 Supplemental Flow at Cruse Gulch & 0.00 & $0.00 \%$ & 0.00 & $0.00 \%$ & 0.00 & $0.00 \%$ \\
\hline 34 & Fountain FRY-ARK RetrnFlw at Fountain WWTF & 0.00 & $0.00 \%$ & 0.00 & $0.00 \%$ & 116.41 & $1.71 \%$ \\
\hline & DOWNSTREAM TOTALS: & 81.62 & & 1941.68 & & 6826.25 & \\
\hline
\end{tabular}

NOTES: * Annual volumes are for current water year--October 1, 2006 through September 30, 2007. 